\title{
ENDIVIDAMENTO AGRÍCOLA: QUÃO COMPROMETIDOS SÃO OS PRODUTORES DO POLO PETROLINA-JUAZEIRO FRENTE A SUAS DÍVIDAS?
}

\author{
Emanoel de Souza Barros* \\ Leonardo Ferraz Xavier ${ }^{\dagger}$ \\ Danielle Tavares Pessoa $¥$ \\ Tiago Farias Sobel $\S$
}

\begin{abstract}
Resumo
O presente artigo busca identificar os determinantes da inadimplência entre os produtores de frutas do Polo Petrolina-Juazeiro. Para tanto, foi utilizado um modelo logit ordenado em função do produtor "escolher" se tornar inadimplente, renegociar sua dívida ou ser adimplente com os setores público e privado. Os resultados mostram que os produtores têm cinco vezes mais chances de se tornarem inadimplentes com o setor público do que com o setor privado. Há divergências quanto aos fatores que explicam a inadimplência frente ao setor público e frente ao setor privado, o que aprofunda a compreensão do tema em questão.
\end{abstract}

Palavras-chave: Agricultura; Inadimplência; Petrolina-Juazeiro; Logit; Probit.

\begin{abstract}
This paper is aimed identifying variables for the default on debts of fruit producers of Petrolina/Juazeiro, regarding both public and private sectors. For that, we use a logit model where the producers may "choose" not paying their debts, renegotiate their debts or repay their debts. The probability of producers who decide not to pay their debts to the public sector is over $50 \%$. There are differences in the variables that explain the non-payment to the public sector and the private sector.
\end{abstract}

Keywords: Agriculture; Default; Petrolina-Juazeiro; Logit; Probit.

JEL classification: C14, C21, Q13

DOI: http://dx.doi.org/10.1590/1413-8050/ea 128281

\footnotetext{
* UFPE (CAA). E-mail: embarros2002@yahoo.fr

$\dagger$ UFRPE. E-mail: leonardoferraz@gmail.com

+ Governo de Pernambuco - Brasil. E-mail: danielle.economia@hotmail.com

$\S$ UFPB. E-mail: tiagosobel@yahoo.com.br
} 


\section{Introdução}

O objetivo do crédito agrícola consiste em (i) disponibilizar recursos financeiros para custeio da produção e investimentos, (ii) além da comercialização dos produtos no período pós-colheita. Segundo autores como Guanziroli (2007) e Ortega \& Só (2005), tais incentivos impulsionam o desenvolvimento da atividade, que, por sua vez, desempenha importante papel na sociedade, associado à provisão de alimentos à população, à geração de emprego e renda, à fixação do homem no campo etc.

Contudo, como destaca uma série de estudos - tais como os de Costa et al. (2008), Cardoso (2005), Faria et al. (2008), Zylbersztajn (2005) - a atividade agrícola implica elevados riscos a seus produtores, tendo em vista a possibilidade de ocorrência de fatores exógenos à ela intrínsecos - tais como intempéries da natureza, doenças e pragas, etc. - capazes de afetar consideravelmente não só o volume produzido, como a sua qualificação e, como consequência, a efetivação dos acordos vigentes entre os agentes.

Nesse contexto, dentre uma série de ações públicas que podem ser direcionadas ao produtor rural - tais como garantia de preços mínimos, seguro rural, pesquisa, extensão e assistência técnica, incentivos à redução de preços de insumos, etc. - é possível destacar as de incentivo ao crédito rural, uma vez que, como destaca Trombin (2007), estas dão condições aos produtores de dispor de meios adequados - tais como insumos, equipamentos, instalações e tecnologias específicas, como fertilizantes e defensivos, variedades de plantas adaptadas, equipamentos de irrigação adequados, etc. — que os viabilizem minimizar os riscos descritos.

Contudo, inerente à provisão do crédito, está a possibilidade de inadimplência em seu pagamento, especialmente, em se tratando da atividade agrícola, dadas as suas incertezas intrínsecas citadas e, por esta razão, ao fato de ela estar historicamente ligada a uma tendência de ação paternalista do Estado brasileiro. Segundo autores como Antão \& Campanholo (2011), Villa Verde (2000) e Costa (2007), esta realidade tende a gerar uma cultura que afeta negativamente o comprometimento do produtor agrícola brasileiro no que tange ao pagamento de suas dívidas, especialmente, junto ao setor público.

Inseridos nesse contexto encontram-se os produtores do Polo PetrolinaJuazeiro, por este se tratar de um dos mais importantes centros produtores de frutas do país, cujo desenvolvimento se deu "de cima para baixo", sob forte influência do governo central. Como destacam autores como Franca (2004) e Sobel (2011), o Polo apresenta um histórico de intervencionismo, onde o governo federal normalmente forneceu uma série de serviços facilitados ao produtor local, dentre os quais destacam-se: o crédito rural e acesso barato à terra, insumos, máquinas e equipamentos. Tal cenário criou uma cultura local paternalista que, em certa medida, perdura (sobretudo no caso dos produtores familiares), o que, acredita-se, tende a influenciar negativamente $o$ comprometimento destes diante dos seus compromissos - destacadamente, com o setor público - , afetando indicadores de inadimplência locais.

Nesse escopo, a presente pesquisa busca exatamente analisar a inadimplência dos produtores agrícolas localizados no Polo Petrolina-Juazeiro. Nesse aspecto, o estudo recai sobre os seguintes conceitos de inadimplência: i) a inadimplência dos produtores frente às dívidas contraídas junto a seus fornecedores de insumos; ii) a inadimplência dos produtores frente às dívidas de regularização fundiária de suas propriedades rurais; e iii) a inadimplência dos 
produtores frente ao crédito tomado junto a instituições financeiras. Portanto, no presente estudo, o tema da inadimplência é abordado de forma ampla, ultrapassando o conceito clássico e relativamente debatido acerca da inadimplência ao crédito fornecido por bancos para a realização de investimentos, comercialização ou à cobertura do custeio produtivo.

Como foco do trabalho, busca-se apontar o quanto o comprometimento dos produtores relativo às dívidas tomadas junto ao setor público é inferior (ou superior) ao comprometimento dos mesmos referentes às dívidas tomadas junto ao setor privado. Nesse aspecto, espera-se que a análise indique que os produtores do Polo tendam a ser mais comprometidos em pagar as dívidas tomadas com o setor privado do que em pagar as dívidas com o setor público. Referida expectativa deriva de uma série de fatores pormenorizados em estudos como os de Gatti et al. (1993), Dias (1991), Villa Verde (2000), Costa (2007), Antão \& Campanholo (2011) e CODEVASF (2007, 2008, 2009 e 2010). De maneira geral, esses fatores podem ser divididos em duas principais vertentes: i) o histórico cultural de que as dívidas públicas ${ }^{1}$ serão perdoadas no futuro, o que configura um problema de principal-agente; e ii) as dívidas contraídas junto ao setor privado ${ }^{2}$ são caracterizadas, normalmente, como dívidas de curto prazo, o que leva o produtor a ser mais comprometido em efetuar seus pagamentos, sob o risco de impedir a continuidade de suas explorações produtivas.

Nesse sentido, as questões básicas em torno da análise do presente trabalho se encontram nos seguintes pontos:

- Qual a dimensão da inadimplência dos produtores no Polo PetrolinaJuazeiro?

- Quais fatores determinam referido fenômeno?

- Quanto os produtores do Polo são mais comprometidos em pagar as dívidas contraídas com o setor privado do que em pagar as dívidas contraídas junto a instituições públicas?

- Há diferenças quanto aos fatores que determinam a inadimplência junto ao setor privado com relação aos que determinam a inadimplência junto ao setor público?

Com vistas a um direcionamento objetivo aos resultados e conclusões do artigo, o mesmo foi organizado em cinco seções, incluindo a presente introdução. Na seção 2 tem-se a revisão da literatura ligada ao tema adimplência/inadimplência na ótica do mercado agrícola. Na Seção 3 "Metodologia", apresentam-se os seguintes tópicos: i) modelo econométrico, com breve descrição do modelo teórico utilizado na pesquisa; ii) dados utilizados, que traz

\footnotetext{
${ }^{1}$ No escopo da presente pesquisa, as instituições tratadas como do setor público referem-se a: i) CODEVASF, instituição responsável pelo recolhimento das dívidas de regularização fundiária nos Perímetros Irrigados do Polo; e ii) bancos públicos, responsáveis pela concessão de financiamentos rurais.

${ }^{2}$ No que concerne aos produtores agrícolas do Polo Petrolina-Juazeiro, as dívidas contraídas junto ao setor privado recaem basicamente sobre o fornecimento de insumos. Dessa maneira, as principais instituições aqui contempladas como do setor privado referem-se a: i) casas comerciais, referentes ao fornecimento de insumos como sementes, adubos, defensivos etc.; e ii) Distrito de Irrigação, instituição privada sem fins lucrativos (associação civil) que fornece a água necessária para a irrigação das culturas exploradas.
} 
informações acerca da amostra estudada; e iii) modelo empírico, em que se apresenta a estratégia de análise. Em seguida, os resultados são apresentados na Seção 4, a qual descreve características particulares aos modelos estimados, bem como traz diagnósticos de ajuste dos mesmos. As principais conclusões do trabalho são apresentadas na Seção 5 .

\section{Revisão da Literatura}

É comum a literatura caracterizar uma relação contratual entre credor e devedor como uma relação com informação assimétrica — em que apenas uma das partes dispõe de informação imprescindível ao negócio - , sobretudo quando se trata do setor agrícola, dadas as incertezas inerentes da atividade. Nesse contexto, baseado em Chaddad \& Lazzarini (2003), é possível identificar dois tipos comuns de problemas a partir das relações contratuais.

Sob uma ótica pré-contratual, é presumível que o devedor omita más informações ao credor com o objetivo de aumentar sua chance de obter o crédito a um custo menor. Sabendo dessa possibilidade, Stiglitz \& Weiss (1981) assinalam que o credor tende a elevar o prêmio exigido, o que acaba atraindo "devedores" de maior risco - pois sob esse cenário apenas projetos de maior retorno esperado mantêm-se atraentes - , gerando efeitos adversos sobre a inadimplência ${ }^{3}$. Já sob uma ótica pós-contratual, é também possível que o devedor, após o fechamento do contrato, tenha incentivos em alterar seu comportamento, realizando ações que também elevam o risco de inadimplência ${ }^{4}$.

Portanto, em razão de ambos os problemas potenciais, credores buscam realizar ações que os viabilizem obter o máximo de informações possíveis sobre o perfil do potencial devedor - por exemplo, analisando o seu histórico de créditos anteriores, seus dados financeiros e contábeis e, especialmente no mercado agrícola, seu perfil tecnológico - visando minimizar eventuais efeitos negativos da informação assimetria, destacadamente, os riscos de inadimplência. Contudo, tais ações incorrem em custos, os quais são denominados de custos de informação (Stiglitz 2000). E, como apontam Azevedo \& Shikida (2004), quanto maior a capacidade do tomador do crédito de esconder do credor o seu potencial de quitação de dívidas, maiores tendem a ser os custos de informação. Entretanto, embora tais ações minimizem o risco de inadimplência, não o elimina por completo, uma vez que agentes oportunistas têm incentivos em formar boa reputação no mercado, "se passando" por agentes honestos.

Assim, tornam-se necessários mecanismos mais complexos de auxílio no cumprimento dos contratos, redundando no que Williamson (1995) denominou de custos de transação. Esses custos podem ser de dois tipos: (i) précontratuais, tais como de negociação, de busca por salvaguardas e punições, de elaboração de contratos, com o tempo despendido para entendimento de legislações e cláusulas contratuais, entre outros; e (ii) pós-contratuais, tais como de monitoramento, fiscalização e controle de desempenhos, punições, renegociação de cláusulas contratuais, entre outros. Como apontam Chaddad \& Lazzarini (2003), estes últimos decorrem das dificuldades de se prever todas as possíveis contingências futuras na fase pré-contratual - dada a existência de racionalidade limitada e oportunismo -, fazendo, portanto, com que

\footnotetext{
${ }^{3}$ Este caso é conhecido na literatura como seleção adversa (Akerlof 1970).

${ }^{4}$ Este caso é conhecido na literatura como risco moral (Arrow 1971).
} 
os contratos sejam inerentemente incompletos e os mecanismos de controle de inadimplência inerentemente imperfeitos ${ }^{5}$.

Dado esse contexto, sabe-se que operações de crédito e a crédito junto aos produtores agrícolas no Brasil são realizadas por uma série de casas comerciais e instituições financeiras públicas e privadas, em que cada uma delas possui funções particulares no processo de fomento da atividade - seja concedendo financiamentos bancários, seja através de vendas de máquinas e insumos a prazo, entre outros. Nesse contexto, é interessante analisar algumas características gerais desses agentes, que influenciam no nível de inadimplência do produtor.

Primeiramente, sabe-se que bancos comerciais, públicos e privados, contam com depósitos de clientes como fonte de recursos, o que os viabilizam recursos estáveis e relativamente baratos para diferentes tipos de financiamentos. Contudo, segundo Chaddad \& Lazzarini (2003), como normalmente não atuam diretamente em mercados agrícolas específicos, eles acabam tendo que gastar uma quantidade relativamente alta de tempo e recursos, na tentativa de reduzir a assimetria de informação junto aos produtores, visando minimizar o potencial de inadimplência. Porém, segundo Staten et al. (1990), produtores honestos e com adequada sanidade financeira podem auxiliar na minimização desses custos de informação, aceitando se submeter a processos rigorosos de avaliação de crédito sinalizando, dessa forma, sua "qualidade" e, consequentemente, podendo obter taxas de juros mais baixas - vale raciocínio similarmente inverso para produtores com alta probabilidade de inadimplência. Nesses termos, como apontam estudos como os de Antão \& Campanholo (2011), Villa Verde (2000) e Costa (2007), estes últimos tendem a buscar credores menos rigorosos, particularmente no Brasil, entes públicos - através de bancos de desenvolvimento e de fomento regionais, linhas de créditos específicas (tais como o Pronaf-crédito ${ }^{6}$ ) e políticas públicas.

Por outro lado, agentes não financeiros que atuam nos Sistemas Agroindustriais - tais como empresas fornecedoras de máquinas, equipamentos e insumos - normalmente enfrentam maiores restrições relativas para viabilizar operações de crédito ao setor agrícola, por não dispor de uma fonte de recursos tão facilitada, devendo, portanto, buscar fontes alternativas - cujas principais, segundo Sherrick et al. (1994), acabam sendo os ativos líquidos da própria empresa, emissão de papéis comerciais e securitização de contas a receber. Por outro lado, por estes apresentarem relações comercias mais íntimas e frequentes com os produtores, Chaddad \& Lazzarini (2003) destacam que eles tendem a incorrer em menores custos de obter informações sobre o perfil tecnológico e a reputação do produtor, viabilizando, por essa via, um menor risco de inadimplência. Ademais, segundo Lazzarini et al. (1999), tais agentes podem reduzir ainda mais os riscos de inadimplência ao realizar contratos interligados com o produtor - por exemplo, por meio de venda de equipamentos atrelada à oferta de um serviço permanente de fornecimento de insu-

\footnotetext{
${ }^{5}$ Como aponta Rocha Júnior (2001), sempre existirá uma falha ou lacuna pela própria complexidade dos contratos e limitação do ser humano.

${ }^{6}$ Criado em 1996, o Programa Nacional de Fortalecimento de Agricultura Familiar (Pronaf) é um Programa de apoio ao desenvolvimento rural, a partir do fortalecimento da agricultura familiar. O PRONAF apresenta três linhas principais de atuação: PRONAF Crédito; PRONAF Infraestrutura e Serviço e o PRONAF Capacitação. O PRONAF Crédito é, dentre estas, a que mais libera recursos, financiando Custeio e Investimento relacionados às atividades agropecuárias, de pesca, de aquicultura, de extrativismo; e relacionados às atividades não-agrícolas, como o artesanato e o turismo rural (PRONAF 2006).
} 
mos e/ou de transferência tecnológica. Esse tipo de contrato possibilita maior controle contra ações oportunistas, pois viabiliza (i) uma melhoria no desempenho técnico-econômico do produtor; e (ii) um maior comprometimento do devedor, visando a manutenção da parceria.

Por sua vez, segundo Chaddad \& Lazzarini (2003), programas governamentais de crédito agrícola são os que possuem as maiores vantagens no que se refere ao custos de captação dos recursos para empréstimos, já que, no geral, tais programas utilizam recursos diretamente do tesouro nacional, que se financia por meio de tributos e de emissão de títulos de dívida pública, os quais apresentam menores riscos em relação aos emitidos por empresas privadas e, portanto, um custo relativamente mais baixo. Por outro lado, autores como Antão \& Campanholo (2011), Villa Verde (2000) e Costa (2007) destacam que, nesse caso, há uma tendência a que os produtores agrícolas sejam menos comprometidos em pagar as dívidas, no geral, em razão do histórico cultural de que as dívidas públicas serão perdoadas no futuro, bem como pelo fato de as dívidas contraídas junto ao setor público serem, normalmente, caracterizadas como de longo prazo, o que leva o produtor a ser, relativamente, menos comprometido em efetuar seus pagamentos, sob o risco de impedir a continuidade de suas explorações produtivas.

\section{Metodologia}

O modelo de resposta binária é um caso especial de modelos com variáveis dependentes discretas, caso normalmente aplicado a estudos de inadimplência, cujo objetivo volta-se a apontar os determinantes que levam um produtor a tornar-se ou não inadimplente frente às dívidas tomadas. Nesse caso, assumem-se apenas dois valores para a resposta aos regressores do modelo: zero ou um. De acordo com Davidson \& MacKinnon (2003), um modelo de resposta binária tenta explicar a probabilidade de o agente "escolher" a alternativa 1 como função de algumas variáveis explicativas observáveis.

Contudo, no presente estudo, além de averiguar a probabilidade de o agente "escolher" a inadimplência (alternativa 1), levar-se-á em consideração outro tipo de "escolha": a opção de renegociar a dívida. Tal conduta estaria em uma situação intermediária entre a adimplência e a inadimplência, visto que: i) a renegociação revelaria uma dificuldade ou descompromisso do produtor em pagar sua dívida, o que é uma situação menos desejada que a adimplência; e ii) contudo, ao mesmo tempo, a renegociação demonstraria um interesse do produtor em quitar seu débito, o que se configura numa situação mais favorável que o efetivo descompromisso com a dívida, ou seja, a inadimplência de fato.

Nesse contexto, cuja variável dependente caracteriza-se como discreta e qualitativa, pretende-se analisar a probabilidade de o agente "escolher" uma dentre três alternativas (adimplência, renegociação da dívida ou inadimplência) como função de fatores observáveis. Para tal tipo de variável dependente, é adequada a aplicação do Logit Ordenado ou do Probit Ordenado, os quais utilizam máxima verossimilhança para fornecer previsões sobre quais fatores influenciam, no caso deste trabalho, a escolha da conduta do produtor frente a suas dívidas contraídas. Segundo Greene (2003), há vários exemplos de variáveis de escolha multinomial que estão inerentemente em ordem, como ratings de títulos, resultados de teste de gosto, pesquisas de opinião, nível de 
cobertura de seguro tomado por um consumidor (nenhum, parcial ou total), emprego (desemprego, tempo parcial e tempo total), entre outros. Em cada um desses casos, embora o resultado seja discreto, o Logit Multinomial ou o Probit Multinomial podem falhar por não contabilizar a natureza ordinal da variável dependente. Assim, o modelo de regressão logística ordinal ou o Probit Ordenado apresentam-se como alternativas para referidas análises.

Teoricamente, a única real diferença entre os modelos Probit e Logit é a forma como os elementos dos parâmetros $\beta$ são escalonados, devido às diferenças entre as variâncias das equações normal-padrão (Probit) e logística (Logit). Na prática, entretanto, ambos os modelos tendem a apresentar resultados bastante similares em relação às probabilidades estimadas.

\subsection{Modelo Econométrico}

Os modelos Logit Ordenado e Probit Ordenado são construídos a partir de uma regressão latente equivalente aos modelos binomiais tradicionais. A partir da função $Y^{*}=X^{\prime} \beta+\epsilon$ não há condições de observar $Y$, mas é possível observar que:

$$
Y=\left\{\begin{array}{l}
0, \wedge Y^{*} \leq \mu_{1} \\
1, \wedge \mu_{1} \leq Y^{*} \leq \mu_{2} \\
2, \wedge \mu_{2} \leq Y^{*} \leq \mu_{3} \\
\ldots, J, \wedge \mu_{J} \leq Y^{*}
\end{array}\right.
$$

Em que os parâmetros $\mu$ são chamados pontos de corte das categorias, sendo desconhecidos e estimados em conjunto ao vetor $\beta$, enquanto $J$ refere-se ao número de categorias cuja variável dependente está dividida. As probabilidades de ocorrência em $Y$ são então estimadas da seguinte maneira:

Em que a função $F(\cdot)$ corresponde à função de densidade logística cumulativa, no caso dos modelos Logit; e à função de densidade normal-padrão cumulativa, no caso dos modelos Probit. As derivadas dessas probabilidades com relação a $X$ correspondem, portanto, aos efeitos marginais de mudanças no regressor.

Para o ajuste do modelo, STATA (2012) sugere o teste razão de verossimilhança (teste LR) que verifica se pelo menos um dos coeficientes da regressão não é igual a zero no modelo. O teste pode ser calculado como $-2[l(\bmod 1)-$ $l(\bmod 2)]$, em que $l(\bmod 1)$ é o logaritmo da probabilidade do modelo sem parâmetros e $l(\bmod 2)$ é o logaritmo da probabilidade do modelo com todos os parâmetros. O teste tem distribuição $\chi^{2}$, cujos graus de liberdade são definidos pelo número de regressores no modelo. A hipótese nula do modelo é que não existem previsores.

Outro tipo de teste de ajuste de modelo é o que analisa a presença de proporcionalidade entre os pontos de corte, ou seja, o teste da razão aproximada da verossimilhança (likelihood ratio test) proposto por Wolfe \& Gould (1998). A hipótese nula é que não existe diferença nos coeficientes entre os modelos. O teste é semelhante ao teste LR, mas difere no número de graus de liberdade, que é igual a $\rho(J-2)$, em que $\rho$ é o número de regressores e $J$ é o número de categorias. A distribuição utilizada também é $\chi^{2}$. Esse teste também é sugerido para identificar a presença de heteroscedasticidade, como apontam Wang \& Kockelman (2005). 
Cabe ainda salientar o teste de Brant (1990), o qual analisa a hipótese de regressões paralelas. Referido teste é importante para a especificação do modelo, visto que, caso referida hipótese seja rejeitada, deve-se optar por um modelo logit ordenado generalizado. Se ainda assim a hipótese não for aceita, sugere-se como alternativa a estimação de um logit de chances proporcionais parciais.

\subsection{Dados Utilizados}

A amostra utilizada parte de uma pesquisa de campo realizada no primeiro trimestre de 2009 e gentilmente cedida pela Plantec Planejamento e Engenharia Agronômica Ltda. A referida empresa é responsável pelos serviços de assistência técnica e extensão rural nos Perímetros Senador Nilo Coelho, Maria Tereza e Bebedouro ${ }^{7}$, conforme contrato estabelecido junto à Companhia de Desenvolvimento dos Vales do São Francisco e do Parnaíba (CODEVASF). A pesquisa contempla informações particulares a 1940 lotes localizados nos perímetros de irrigação acima citados.

As informações relativas à inadimplência dos produtores, tratadas na pesquisa de campo, contemplam quatro instituições: i) bancos públicos, relativo ao crédito tomado pelos produtores para a realização de investimentos, comercialização e/ou custeio produtivo; ii) CODEVASF, referente às dívidas de regularização fundiária das propriedades; iii) Distrito de Irrigação, relativo às dívidas de fornecimento de água para irrigação das explorações; e iv) casas comerciais, referente às dívidas de fornecimento de insumos contraídas junto aos fornecedores. Para os quatro casos, questões foram levantadas quanto à situação da dívida, ou seja, se o produtor encontra-se em situação de adimplência, renegociação da dívida ou inadimplência.

Vale destacar que a situação da dívida, neste trabalho, é tomada diante das seguintes hipóteses: i) um produtor com dívidas junto aos bancos públicos só pode ser assim tratado se o mesmo contraiu algum tipo de financiamento ${ }^{8}$; ii) todos os produtores da amostra estão ou estiveram com dívidas junto à CODEVASF - assim, um produtor que não está em dívida junto a essa instituição será tratado como adimplente, enquanto aqueles que ainda estão em dívida poderão ser tratados como adimplentes, renegociantes ou inadimplentes, a depender de sua resposta -; iii) todos os produtores têm dívidas junto ao Distrito de Irrigação, visto que todos produzem e, portanto, participam do rateio de fornecimento de água feito por essa instituição; iv) todos os produtores têm dívidas junto às casas comerciais e, se compram à vista, serão aqui tratados como adimplentes, visto que pagaram no ato da compra. Dessa maneira, todos os produtores da amostra ${ }^{9}$ serão tratados em uma das situações aqui analisadas — adimplência, renegociação da dívida ou inadimplência de acordo com a resposta dada por estes em cada questionário.

\footnotetext{
${ }^{7}$ A área produtiva do Polo Petrolina-Juazeiro é dividida em perímetros irrigados geridos pela CODEVASF. Os Perímetros Senador Nilo Coelho, Maria Tereza e Bebedouro somam mais de 55\% das áreas irrigadas de todos os perímetros do Polo, mais de $75 \%$ dos colonos que atuam nos mesmos e quase $40 \%$ das empresas produtoras (CODEVASF 2012).

${ }^{8}$ Assim, produtores que nunca contraíram financiamento junto aos bancos públicos serão excluídos da amostra quando essa instituição for analisada.

${ }^{9}$ Exceto no caso dos que nunca contraíram financiamento junto aos bancos públicos, pelas razões acima destacadas.
} 


\subsection{Modelo Empírico}

Com o objetivo de estimar a probabilidade de que o produtor do Polo PetrolinaJuazeiro, dadas determinadas características, possa vir a ser um potencial tomador de dívidas adimplente, renegociante ou inadimplente, considera-se como estratégia empírica a utilização de um modelo com variável dependente qualitativa ordinal. Ou seja, tem-se como resposta uma variável que assume o valor 0 para o produtor adimplente, o valor 1 para o renegociante e o valor 2 caso o mesmo esteja na situação de inadimplência.

Para responder ao questionamento sobre os fatores que determinam o fenômeno da inadimplência no Polo, a variável dependente utilizada poderá assumir os seguintes valores:

- 0 , caso o produtor esteja em situação de adimplência nas quatro instituições aqui tratadas (bancos públicos, CODEVASF, Distrito de Irrigação e casas comerciais);

- 1, caso o produtor esteja em situação de renegociação da dívida em pelo menos uma das quatro instituições aqui tratadas, desde que não esteja inadimplente em qualquer outra das quatro instituições;

- 2, caso o produtor esteja em situação de inadimplência em pelo menos uma das quatro instituições aqui tratadas.

Assim, a variável dependente assumirá valor 2 quando o produtor estiver inadimplente em uma das quatro instituições aqui tratadas, independente de sua situação da dívida com as outras três instituições. Se o produtor não estiver inadimplente em nenhuma das instituições, basta que esteja em processo de renegociação com ao menos uma para que a variável dependente assuma o valor 1 . Por fim, a variável dependente assumirá valor 0 somente quando o produtor encontre-se em situação de adimplência com todas as instituições aqui tratadas.

Definida a estrutura da variável dependente, esta será regredida em função de um conjunto de fatores para se estabelecer quais características podem influenciar as chances de o produtor se tornar adimplente, renegociante ou inadimplente. Seguindo Costa (2007) e Antão \& Campanholo (2011), acerca dos fatores capazes de explicar a inadimplência rural, o modelo empírico estimado deve incluir variáveis relevantes a fim de se determinar a situação das dívidas. A tabela 1 apresenta a lista de variáveis utilizadas para a estimação do modelo empírico básico, baseada nos trabalhos acima citados. Nesta, encontra-se a descrição das variáveis e seus valores conforme foi disposto nos questionários aplicados na pesquisa de campo.

As demais variáveis explicativas podem ser subdivididas em categorias que contemplam várias características do produtor ou do lote:

- Variáveis de localização: variáveis dummy para cada um dos onze Núcleos do Perímetro Nilo Coelho (N1 a N11) ${ }^{10}$, uma variável dummy para o Perímetro Maria Tereza e uma variável dummy para o Perímetro Bebedouro;

\footnotetext{
${ }^{10}$ O Perímetro Senador Nilo Coelho é dividido em onze núcleos distintos, com particularidades quanto às distâncias ao centro urbano de Petrolina e Juazeiro, perfil produtivo explorado, disponibilidade de mão de obra etc.
} 
Tabela 1: Variáveis básicas utilizadas no modelo empírico

\begin{tabular}{|c|c|c|}
\hline Variável & Descrição & Unidade / Valores Atribuídos \\
\hline AREA & Área plantada & Hectares / Valores contínuos. \\
\hline RENDA & Renda bruta mensal do lote & 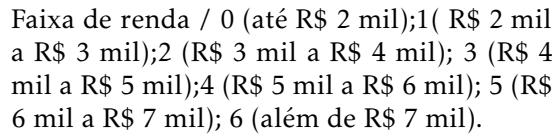 \\
\hline ESCOL & Escolaridade do produtor & $\begin{array}{l}\text { Faixa de escolaridade / 0(analfabeto); } 1 \text { (al- } \\
\text { fabetizado);2 (Ensino Fundamental I); } 3 \text { (En- } \\
\text { sino Fundamental II); } 4 \text { (Ensino Médio ou } \\
\text { Técnico); } 5 \text { (Ensino Superior). }\end{array}$ \\
\hline IDADE & Idade do produtor & $\begin{array}{l}\text { Faixa etária / } 0 \text { (até } 30 \text { anos); } 1 \text { ( } 30 \text { a } 40 \\
\text { anos);2 ( } 40 \text { a } 50 \text { anos); } 3 \text { ( } 50 \text { a } 60 \text { anos); } 4 \\
\text { (além de } 60 \text { anos). }\end{array}$ \\
\hline
\end{tabular}

Fonte:elaboração própria.

- Culturas exploradas na propriedade: sete variáveis correspondentes aos percentuais da área produzida cultivadas com manga, uva, banana, goiaba, acerola, coco e outras culturas;

- Tempo no lote: variável discreta categórica, referente ao tempo em que o produtor atua no Polo, variando de 0 a 4 segundo as faixas de 0 a 5 anos, de 6 a 10 anos, de 11 a 15 anos, de 16 a 20 anos e acima de 20 anos;

- Características do produtor: dez variáveis referentes a ter atividade em outro lote, número de lotes em que atua, ser colono, ser casado, ter filhos dependentes, ser do sexo feminino, ser portador de necessidades físicas, ter carro próprio, ter renda extra-rural e ter formação escolar na área agrícola;

- Características produtivas do lote: seis variáveis referentes a realizar análise de solo, realizar análise foliar, adotar recomendações de análises laboratoriais, adotar manejo específico para aumento do rendimento das culturas, contar com sistema de irrigação especificamente dimensionado para as culturas exploradas na propriedade e contar com certificação internacional (como Globalgap);

- Gestão do negócio: seis variáveis referentes ao número de funcionários, ter funcionário na administração do negócio, participar de treinamentos (produtor e/ou funcionários), participar de associação de produtores, realizar planejamento/controle financeiro e realizar vendas sob contrato.

Dessa forma, a situação da dívida contraída pelo produtor diante das quatro instituições aqui tratadas será contemplada como variável dependente a ser regredida em função das diversas características aqui relacionadas. Assim, será possível responder ao questionamento inicialmente levantado sobre quais fatores determinam o fenômeno da inadimplência no Polo PetrolinaJuazeiro. Além disso, será possível estimar qual a probabilidade de um "produtor médio" do Polo ${ }^{11}$ ser adimplente em suas dívidas, renegociante ou inadimplente de fato. Dessa forma, será possível apontar a dimensão da inadimplência no Polo, indicando quais as chances de seus produtores se tornarem adimplentes, renegociantes ou inadimplentes.

\footnotetext{
${ }^{11} \mathrm{O}$ "produtor médio" caracteriza-se por valores das variáveis explicativas correspondentes às medianas amostrais.
} 
Contudo, outros questionamentos relacionados aos objetivos deste trabalho ainda devem ser explorados, ou seja:

- Quanto os produtores do Polo são mais comprometidos em pagar as dívidas contraídas com o setor privado do que são em pagar as dívidas contraídas junto a instituições públicas?

- Há diferenças quanto aos fatores que determinam a inadimplência junto ao setor privado com relação aos que determinam a inadimplência junto ao setor público?

Para responder tais questionamentos, dois outros modelos serão estimados (doravante chamados modelos específicos), sendo a estrutura destes semelhante àquela apresentada até o momento (modelo conjunto, que leva em consideração as quatro instituições aqui tratadas). Nesse sentido, é necessário qualificar o que será tratado como dívidas contraídas com o setor público e como dívidas contraídas com o setor privado. Dentre as quatro instituições tratadas na pesquisa de campo, duas são qualificadas como dívidas com o setor público, quais sejam os bancos públicos e a CODEVASF; enquanto duas são relacionadas ao setor privado, quais sejam o Distrito de Irrigação e as casas comerciais.

Quanto ao modelo específico que contempla a análise do setor público, a estrutura da variável dependente tomará o mesmo formato do modelo conjunto, mas em vez de considerar as quatro instituições, levará em conta a situação da dívida apenas com os bancos públicos e com a CODEVASF. Dessa forma, a variável dependente assumirá valor 2 quando o produtor estiver inadimplente em uma dessas duas instituições, independente de sua situação da dívida com a outra; valor 1 quando o produtor estiver em renegociação em uma dessas instituições, desde que não esteja inadimplente na outra; e valor 0 quando o produtor estiver adimplente tanto com os bancos públicos, quanto com a CODEVASF. As variáveis explicativas, por sua vez, serão as mesmas relacionadas anteriormente, com respeito ao modelo conjunto.

De forma análoga, para o modelo específico que contempla a análise do setor privado, a estrutura da variável dependente levará em conta a situação da dívida apenas com o Distrito de Irrigação e as casas comerciais. Dessa forma, a variável dependente assumirá valor 2 quando o produtor estiver inadimplente em uma dessas duas instituições, independente de sua situação da dívida com a outra; valor 1 quando o produtor estiver em renegociação em uma dessas instituições, desde que não esteja inadimplente na outra; e valor 0 quando o produtor estiver adimplente tanto com o Distrito de Irrigação, quanto com as casas comerciais. Novamente, as variáveis explicativas serão as mesmas relacionadas anteriormente.

Dessa maneira, será possível identificar se existem diferenças com relação aos fatores que explicam a inadimplência dos produtores frente ao setor público e aqueles que explicam a inadimplência frente ao setor privado. Além disso, visto que é possível estimar a probabilidade de adimplência do "produtor médio" do Polo em cada caso, pode-se dar apontamentos sobre o quanto os produtores são mais comprometidos em pagar dívidas com o setor privado do que são em pagar dívidas com o setor público. 


\section{Resultados}

De acordo com Caouette et al. (1999), o risco de crédito está relacionado à capacidade de pagamento e características relacionadas ao caráter do devedor, sendo o primeiro fator o principal responsável pela inadimplência. Assim, conforme sugerem os autores, o modelo estimado deve considerar apenas variáveis com potencial de exercer influência sobre a capacidade de pagamento dos produtores rurais, considerando que incapacidade de pagamento está diretamente relacionada com a inadimplência, minimizando, portanto, a perspectiva do não pagamento ocorrer em função da vontade do devedor, aliandose a isso a falta de elementos que viabilizem a análise sob esse ponto de vista.

Ademais, estimou-se os modelos Logit Ordenado e Probit Ordenado a fim de se verificar o efeito das variáveis expostas na Tabela 1 sobre a probabilidade de inadimplência do produtor rural no Polo Petrolina-Juazeiro. Para tanto, utilizou-se o método de máxima verossimilhança $(M L)$, conforme apresentado no item referente à metodologia. Como referidos modelos são essencialmente heteroscedásticos, tornando os desvios-padrão estimados viesados, utilizouse para a estimação da matriz de variância-covariância dos resíduos, desviospadrão robustos à heteroscedasticidade. De acordo com Greene (2003), o uso de desvio-padrão robusto não altera os coeficientes estimados, entretanto, devido ao fato de que os erros-padrão são alterados, as estatísticas de teste fornecerão $\mathrm{p}$-valores extremamente precisos.

\subsection{Modelo Conjunto: Diagnóstico da Inadimplência Geral no Polo}

Os resultados obtidos para o modelo básico são descritos na tabela 2 abaixo. As estatísticas LR $\chi^{2}(4)$ e log pseudo-verossimilhança apontam para modelos apropriados, em que se verifica, tanto para o modelo Logit Ordenado, quanto para o Probit Ordenado, que a probabilidade de inadimplência tende a se elevar quanto maior o porte do produtor (captado pela variável AREA), enquanto tende a se reduzir quanto maior a renda obtida no lote, bem como a escolaridade e a idade do produtor. O número de observações utilizadas corresponde a 744 lotes, tendo em vista a ocorrência de missing values relativos às respostas sobre a situação da dívida dos produtores em cada uma das quatro instituições aqui tratadas (bancos públicos, CODEVASF, Distrito de Irrigação e casas comerciais), que formam a variável dependente; bem como missing values relativos às variáveis explicativas. Vale destacar, ainda, que a amostra utilizada na estimação desse modelo exclui os produtores que nunca contraíram crédito junto a bancos públicos, visto que esta é uma das instituições que dimensionam a variável dependente.

Ao se considerar a inclusão de outras variáveis ao modelo básico, conforme destacado na descrição metodológica do modelo empírico, verificou-se que variáveis auxiliares podem dar maior poder explicativo à probabilidade de inadimplência. Ao se testar o conjunto de variáveis auxiliares, o modelo de melhor ajuste aos dados amostrais é apresentado na tabela 3.

Novamente, as estatísticas LR $\chi^{2}(10)$ e log pseudo-verossimilhança apontam para modelos apropriados. Tanto para o modelo Logit Ordenado, quanto para o Probit Ordenado, todas as variáveis mostraram-se significativas para explicar a situação das dívidas dos produtores da amostra - exceto no caso da dummy COLONO no modelo Logit -. Cabe destacar que, relativo ao modelo básico, apenas as variáveis RENDA e IDADE apresentaram instabilidade nos 
Tabela 2: Estatísticas do modelo conjunto básico

\begin{tabular}{|c|c|c|}
\hline Discriminação & Logit Ordenado & Probit Ordenado \\
\hline & Coeficientes Ef. Marginais ${ }^{1}$ & Coeficientes Ef. Marginais ${ }^{1}$ \\
\hline AREA & $0,019^{* *}$ & $0,018^{* *}$ \\
\hline RENDA & $-0,061^{*}$ & $-0,057^{*}$ \\
\hline ESCOL & $-0,050^{*}$ & $-0,050^{*}$ \\
\hline IDADE & $-0,045^{*}$ & $-0,043^{*}$ \\
\hline Estatística LR $\chi^{2}(10)$ & $76,49^{*}$ & $79,39^{*}$ \\
\hline Log pseudo-verossimilhança & $-712,51$ & $-712,59$ \\
\hline $\mathrm{N}^{\mathrm{o}}$ de observações & \multicolumn{2}{|c|}{744} \\
\hline
\end{tabular}

efeitos marginais, o que pode ser justificado pela inclusão de variáveis correlacionadas nos modelos de melhor ajuste. O número de observações utilizadas corresponde a 659 lotes, tendo em vista a ocorrência de missing values.

Tabela 3: Estatísticas do modelo conjunto de melhor ajuste

\begin{tabular}{|c|c|c|c|c|}
\hline \multirow[t]{2}{*}{ Discriminação } & \multicolumn{2}{|c|}{ Logit Ordenado } & \multicolumn{2}{|c|}{ Probit Ordenado } \\
\hline & Coeficientes & Ef. Marginais ${ }^{1}$ & Coeficientes & Ef. Marginais ${ }^{1}$ \\
\hline AREA & $0,09^{*}$ & $0,022^{*}$ & $0,05^{* *}$ & $0,020^{* *}$ \\
\hline RENDA & $-0,13^{*}$ & $-0,032^{*}$ & $-0,07^{*}$ & $-0,029^{*}$ \\
\hline ESCOL & $-0,21^{*}$ & $-0,053^{*}$ & $-0,13^{*}$ & $-0,051^{*}$ \\
\hline IDADE & $-0,33^{*}$ & $-0,083^{*}$ & $-0,20^{*}$ & $-0,079^{*}$ \\
\hline FILHOS & $0,44^{* * *}$ & $0,106^{* * *}$ & $0,25^{* * *}$ & $0,097^{* * *}$ \\
\hline COLONO & 0,29 & 0,073 & $0,21^{* * *}$ & $0,082^{* * *}$ \\
\hline NUMLOTES & $0,08^{* * *}$ & $0,020^{* * * *}$ & $0,05^{* * *}$ & $0,021^{* * *}$ \\
\hline CERTIF & $-0,73^{*}$ & $-0,170^{*}$ & $-0,42^{*}$ & $-0,158^{*}$ \\
\hline PLANEJ & $-0,18^{*}$ & $-0,044^{*}$ & $-0,11^{*}$ & $-0,045^{*}$ \\
\hline NUMFUNC & $-0,05^{* *}$ & $-0,012^{* *}$ & $-0,03^{*}$ & $-0,011^{*}$ \\
\hline Estatística LR $\chi^{2}(10)$ & \multicolumn{2}{|c|}{$103,63^{*}$} & \multicolumn{2}{|c|}{$111,52^{*}$} \\
\hline Log pseudo-verossimilhança & \multicolumn{2}{|c|}{$-609,61$} & \multicolumn{2}{|c|}{$-608,85$} \\
\hline No de observações & \multicolumn{4}{|c|}{659} \\
\hline
\end{tabular}

Antes de analisar os resultados desse modelo, é interessante comentar as variáveis testadas que foram redundantes à identificação do mesmo ${ }^{12}$. Quanto às variáveis de localização, verificou-se que o simples fato de o produtor estar localizado em um ou outro Núcleo do Perímetro Nilo Coelho, ou nos Perímetros Maria Tereza e Bebedouro, não é capaz de explicar (de forma estatisticamente significante) o comportamento dos produtores frente às dívidas contraídas. De forma análoga, o tipo de cultura ou culturas exploradas na propriedade também não explica referido comportamento.

\footnotetext{
${ }^{12}$ Para mais detalhes relacionados às variáveis auxiliares, vide descrição metodológica do modelo empírico.
} 
O tempo no lote, que poderia captar a experiência do produtor com a atividade agrícola, também não chegou a explicar a situação das dívidas do produtor, assim como características como ser casado, ser do sexo feminino, ser portador de necessidades físicas, ter carro próprio, ter renda extra-rural e ter formação escolar na área agrícola. Contar com sistema de irrigação dimensionado especificamente para as culturas exploradas na propriedade também não se mostrou estatisticamente significante. Outras variáveis, estas relacionadas à gestão do negócio, também não seriam capazes de explicar a variável dependente, quais sejam: ter funcionário na administração do negócio, participar de treinamentos, participar de associação de produtores e realizar vendas sob contrato.

De certa forma, esses resultados contrariam a hipótese de que a situação de inadimplência esteja relacionada com a capacidade de pagamento do devedor, visto que as variáveis descartadas estão aparentemente correlacionadas a tal capacidade. Contudo, os testes de redundância realizados sobre essas variáveis indicam que os fatores relacionados na tabela 3 são suficientes para explicar a situação das dívidas dos produtores da amostra. Para a análise desses fatores, é necessário, porém, apresentar os efeitos marginais referentes a cada variável.

Os efeitos marginais indicam o quanto à probabilidade de ocorrência em uma das categorias da variável dependente (adimplente, renegociante ou inadimplente) pode variar diante de alterações em determinada variável explanatória. Para tanto, é necessário estipular uma condição inicial referente às características do produtor, o que normalmente é feito sobre um "produtor médio", que assumiria valores para as variáveis explicativas do modelo correspondentes à média ou à mediana amostral em cada característica ${ }^{13}$. Assim, a análise dos efeitos marginais parte de um choque em certa característica do "produtor médio" para se verificar as alterações na distribuição de probabilidades de ocorrência em uma das categorias da variável dependente.

$\mathrm{Na}$ amostra completa, de 1940 lotes, as medianas amostrais das variáveis explanatórias dispostas na tabela 3 correspondem a: AREA $=6,3$ (área plantada no lote de 6,3 hectares); RENDA = 1 (renda bruta mensal do lote entre R\$ 2 mil e R\$ 3 mil); ESCOL = 4 (com Ensino Médio ou Técnico); IDADE = 3 (entre 50 e 60 anos); FILHOS $=1$ (tem filhos dependentes); COLONO =0 (é caracterizado como colono); NUMLOTES $=1$ (atua em apenas um lote); CER$\mathrm{TIF}=0$ (não certificado); PLANEJ = 3 (faz planejamento de negócio de forma parcial-forte ${ }^{14}$ ); e NUMFUNC $=1$ (conta com um único funcionário). Estas seriam, portanto, as características do "produtor médio" do Polo Petrolina Juazeiro.

Antes de explanar sobre os efeitos marginais de cada variável explicativa, é importante destacar que, de acordo com as estimativas realizadas a partir dos resultados da tabela 3, o "produtor médio" teria a seguinte distribuição de probabilidades de ocorrência em cada categoria da variável dependente ${ }^{15}$ : chan-

\footnotetext{
${ }^{13}$ A opção entre média e mediana depende da distribuição da variável (na existência de outliers, p.ex., é preferível usar a mediana em vez da média), bem como do tipo de variável (para variáveis discretas, é preferível usar a mediana com vistas a manter a característica de variável discreta).

${ }^{14}$ A variável PLANEJ leva em consideração respostas a duas questões referentes às práticas de controle de custos e receitas, bem como pesquisa de preços de insumos. As respostas possíveis seriam "não realiza", "realiza parcialmente" ou "realiza". Assim, da combinação desses resultados, a variável PLANEJ foi criada variando de zero a quatro, de forma discreta e categórica, elevando-se conforme o grau de planejamento financeiro na gestão do negócio.

${ }^{15}$ Os resultados encontrados para essa distribuição mostraram que as estimativas dos modelos
} 
ces de $14,64 \%$ de ser adimplente nas quatro instituições aqui tratadas (bancos comerciais, CODEVASF, Distrito de Irrigação e casas comerciais); 39,26\% de renegociar dívidas com pelo menos uma das quatro instituições; e 46,09\% de se tornar inadimplente com pelo menos uma das quatro instituições.

Esse resultado, portanto, é tratado como a dimensão do fenômeno da inadimplência no Polo Petrolina-Juazeiro, a qual representa níveis alarmantes quanto ao risco de crédito na região. Tais resultados ainda estão de acordo com as observações amostrais de que $18,1 \%$ dos produtores encontram-se na categoria de adimplência, 30,7\% encontram-se na categoria de renegociante e $51,2 \%$ encontra-se no estrato de inadimplência.

Passando finalmente à análise dos fatores determinantes da inadimplência na região, de acordo com os resultados do modelo conjunto de melhor ajuste, vale ressaltar os seguintes pontos:

- Um choque de $+1,0$ ha sobre a área produzida(AREA $=7,3$ ) leva o "produtor médio" a reduzir as chances de adimplência para 13,51\%, reduzir as chances de renegociação para $38,38 \%$ e elevar as chances de inadimplência para $48,11 \%$;

- Por sua vez, o aumento de uma faixa de renda $($ RENDA $=2)$ leva o mesmo a apresentar chances de $16,38 \%, 40,41 \%$ e $43,21 \%$ (respectivamente para adimplência, renegociação e inadimplência);

- O aumento de uma faixa de escolaridade $(\mathrm{ESCOL}=5)$ altera a distribuição de probabilidades para 17,81\% (adimplência), 41,18\% (renegociação) e 41,01\% (inadimplência);

- O aumento de uma faixa de idade (IDADE $=4$ ) leva o "produtor médio" a variar sua distribuição para 19,69\% (adimplência), 43,35\% (renegociação) e 38,31\% (inadimplência);

- Caso o mesmo não tivesse filhos dependentes (FILHOS $=0$ ), sua distribuição passaria a ser de 21,15\% (adimplência), 42,49\% (renegociação) e $36,36 \%$ (inadimplência);

- Por sua vez, se o mesmo fosse caracterizado como colono $(\mathrm{COLONO}=$ 1), sua distribuição passaria para 10,41\% (adimplência), 35,26\% (renegociação) e 54,33\% (inadimplência);

- Caso o "produtor médio" atuasse em mais um lote (LOTE $=2)$, sua distribuição passaria para 13,49\% (adimplência), 38,36\% (renegociação) e $48,15 \%$ (inadimplência);

- Se o mesmo fosse certificado (CERTIF $=1)$, sua distribuição de probabilidades passaria a ser de 26,34\% (adimplência), 43,40\% (renegociação) e $30,25 \%$ (inadimplência);

- Caso realizasse completamente práticas de gestão financeira (PLANEJ = 5), a distribuição seria de 17,40\% (adimplência), 40,97\% (renegociação) e 41,63\% (inadimplência);

Logit e Probit Ordenado, conforme esperado, são praticamente idênticas. Contudo, visto que a estatística LR $\chi^{2}(10)$ no modelo Probit é um pouco maior frente à mesma estatística no Logit, a análise dos efeitos marginais será realizada por meio das estimativas do Probit. 
- Por fim, com a admissão de mais um funcionário no lote do "produtor médio" (NUMFUNC = 2), as chances seriam de 15,32\% (adimplência), $39,74 \%$ (renegociação) e 44,95\% (inadimplência).

A brevidade quanto aos comentários relativos a esses resultados deve-se à intenção de pormenorizar a análise relativa aos modelos específicos referentes aos setores público e privado. Ademais, demonstra-se que a inadimplência geral no Polo, analisada pela estimativa do modelo conjunto - relativo à situação da dívida dos produtores frente às instituições bancos públicos, CODEVASF, Distrito de Irrigação e casas comerciais - , relaciona-se positivamente com fatores como tamanho da propriedade, existência de filhos dependentes, ser caracterizado como colono e número de lotes em que o produtor atua. Por outro lado, as chances de adimplência tendem a se relacionar positivamente com fatores como renda do lote, escolaridade e idade do produtor, certificação produtiva (Globalgap), gestão financeira do negócio e número de funcionários no lote.

Entretanto, como descrito anteriormente, um ponto importante acerca dos fatores que influenciam a inadimplência no Polo pode estar relacionado ao tipo de instituição cujo produtor contrai suas dívidas. Nesse sentido, dois outros modelos são apresentados com vistas a qualificar o tipo de dívida, se contraída junto ao setor público ou se contraída junto ao setor privado. Nesse aspecto, espera-se que a distribuição de probabilidades nas categorias de situação das dívidas, bem como os fatores determinantes dessa ocorrência sejam divergentes segundo o tipo de dívida.

\subsection{Modelos Específicos: Diagnóstico da Inadimplência sobre Setores Público e Privado}

A estimação dos modelos específicos básicos encontra-se na tabela 4 a seguir ${ }^{16}$. Verifica-se que as estatísticas LR $\chi^{2}(4)$ e log pseudo-verossimilhança apontam para modelos apropriados. Para o modelo específico relativo às dívidas com o setor público, os sinais dos coeficientes são equivalentes ao modelo conjunto básico apresentado na tabela 2 , sendo semelhantes também os p-valores e efeitos marginais. Contudo, para o modelo específico relativo às dívidas com o setor privado, o modelo básico indica que as variáveis AREA, ESCOL e IDADE seriam estatisticamente insignificantes para explicar a inadimplência, o que evidencia a necessidade de se testar variáveis auxiliares.

Vale destacar que o número de observações varia em cada tipo de modelo. Isso ocorre porque, no caso do modelo específico relativo à dívida do setor público, sua variável dependente leva em consideração a situação da dívida frente às instituições bancos comerciais e CODEVASF; enquanto no caso do modelo para o setor privado, sua variável dependente leva em conta a situação da dívida com as instituições Distrito de Irrigação e casas comerciais. Além disso, cabe lembrar que, ao se considerar a situação da dívida com bancos comerciais para a formulação da variável dependente no modelo de setor

\footnotetext{
${ }^{16}$ Pelos mesmos motivos apresentados quanto à análise dos efeitos marginais do modelo conjunto, a apresentação dos resultados referentes aos modelos específicos (setor público e setor privado) será referente às estimativas do modelo Probit Ordenado.
} 
Tabela 4: Estatísticas dos modelos específicos básicos

\begin{tabular}{lcccc}
\hline Discriminação & \multicolumn{2}{c}{ Dívida com Setor Público } & \multicolumn{2}{c}{ Dívida com Setor Privado } \\
\hline & Coeficientes & Ef. Marginais & Coeficientes & Ef. Marginais ${ }^{1}$ \\
\hline AREA & $0,04^{* *}$ & $0,017^{* *}$ & 0,02 & 0,004 \\
RENDA & $-0,15^{*}$ & $-0,059^{*}$ & $-0,07^{*}$ & $-0,013^{*}$ \\
ESCOL & $-0,11^{*}$ & $-0,043^{*}$ & 0,00 & 0,000 \\
IDADE & $-0,08^{* *}$ & $-0,032^{* *}$ & $-0,04$ & $-0,008$ \\
Estatística LR & $79,67^{*}$ & $11,36^{* *}$ & \multicolumn{2}{c}{$-799,36$} \\
Log pseudo-verossimilhança & \multicolumn{3}{c}{$-760,83$} & \multicolumn{2}{c}{1030} \\
No de observações & \multicolumn{2}{c}{782} & \\
\hline
\end{tabular}

* Significativo a $1 \% .{ }^{* *}$ Significativo a $5 \%$. ${ }^{* * *}$ Significativo a $10 \%$.

Variável dependente: categoria 0 - adimplente; categoria 1 - renegociante; categoria 2 - inadimplente.

1 Trata-se dos efeitos marginais de alterações em cada variável explanatória sobre as chances de ocorrência na categoria 2 (aqui apresentados apenas para verificação da estabilidade dos modelos). Fonte: elaboração própria.

público, o número de observações neste será ainda reduzido devido à exclusão daqueles entrevistados que nunca contraíram crédito para financiamento ${ }^{17}$.

Ao se considerar a inclusão de outras variáveis aos modelos específicos básicos, semelhante ao realizado na análise do modelo conjunto, verificou-se que variáveis auxiliares podem dar maior poder explicativo à probabilidade de inadimplência tanto relativa à dívida com o setor público, quanto com respeito à dívida com o setor privado.

Ao se testar o conjunto de variáveis auxiliares, o modelo de melhor ajuste aos dados amostrais utilizados para a estimação do modelo relativo ao setor público considera as variáveis AREA, RENDA, ESCOL, IDADE, COLONO, NUMLOTES, CERTIF, PLANEJ, NUMFUNC e CONDFUNC. Portanto, o modelo específico que vem a elucidar os fatores que influenciam a situação do produtor quanto a suas dívidas com o setor público é semelhante ao modelo conjunto, exceto pela ocorrência de impactos significativos causados pela variável CONDFUNC (dummy de lote conduzido por funcionário) e pela verificação de que a variável FILHOS (produtor com filho ou filhos dependentes) é estatisticamente insignificante para explicar a situação em que o produtor se encontra com respeito à dívida com o setor público. Além disso, os efeitos marginais de certas variáveis têm seus valores alterados consideravelmente, como será apresentado posteriormente com mais detalhe.

Por sua vez, o modelo de melhor ajuste relativo às dívidas com o setor privado demonstrou que a estrutura de fatores de influência é de fato divergente. Nesse aspecto, variáveis como AREA, ESCOL, COLONO, NUMLOTES, NUMFUNC e CONDFUNC são apontadas como redundantes ao modelo de melhor ajuste que, por sua vez, passa a considerar fatores que antes eram tratados como não explicativos, quais sejam RENDEXTR (dummy de renda extrarrural, seja através de aposentadoria ou outra atividade), PROD (faz manejo produtivo adequado ${ }^{18}$ ), ASSOC (dummy de participação em associações)

\footnotetext{
${ }^{17}$ Como explicado na descrição metodológica do modelo empírico, não seria possível tomar como adimplente um produtor que nunca contraiu crédito junto aos bancos públicos.

${ }^{18}$ Semelhante à variável PLANEJ, PROD leva em consideração respostas a questões referentes a práticas culturais que elevam a produtividade destas, quais sejam: realização de análises de solo e foliar, adoção das recomendações de análises laboratoriais, além de adoção de manejo específico para aumento do rendimento das culturas. As respostas possíveis seriam "não realiza",
} 
e SEMCONTR (dummy de venda principalmente através de transações sem qualquer tipo de contrato, mesmo informal).

Os resultados para os modelos específicos de melhor ajuste, tanto relativo às dívidas com o setor público, quanto às dívidas com o setor privado, são apresentados na tabela 5. Vale destacar que os campos vazios representam variáveis redundantes a cada tipo de modelo.

Novamente, as estatísticas LR $-\chi^{2}(10)$ para o modelo de setor público e $\chi^{2}(9)$ para o modelo de setor privado - e log pseudo-verossimilhança apontam para modelos apropriados. Para ambos os casos, todas as variáveis mostraramse significativas para explicar a situação das dívidas dos produtores da amostra. Cabe destacar que, relativo ao modelo básico específico para o setor público, apenas as variáveis RENDA e IDADE apresentaram instabilidade nos efeitos marginais, o que pode ser justificado pela inclusão de variáveis correlacionadas no modelo de melhor ajuste. De forma análoga, para o modelo de setor privado, a instabilidade sobre os efeitos marginais também ocorre para a variável RENDA. Quanto ao número de observações utilizadas, tendo em vista a ocorrência de missing values, a amostra utilizada para o modelo de setor público corresponde a 715 lotes, enquanto equivale a 758 lotes no modelo de setorprivado.

Tabela 5: Estatísticas dos modelos específicos de melhor ajuste

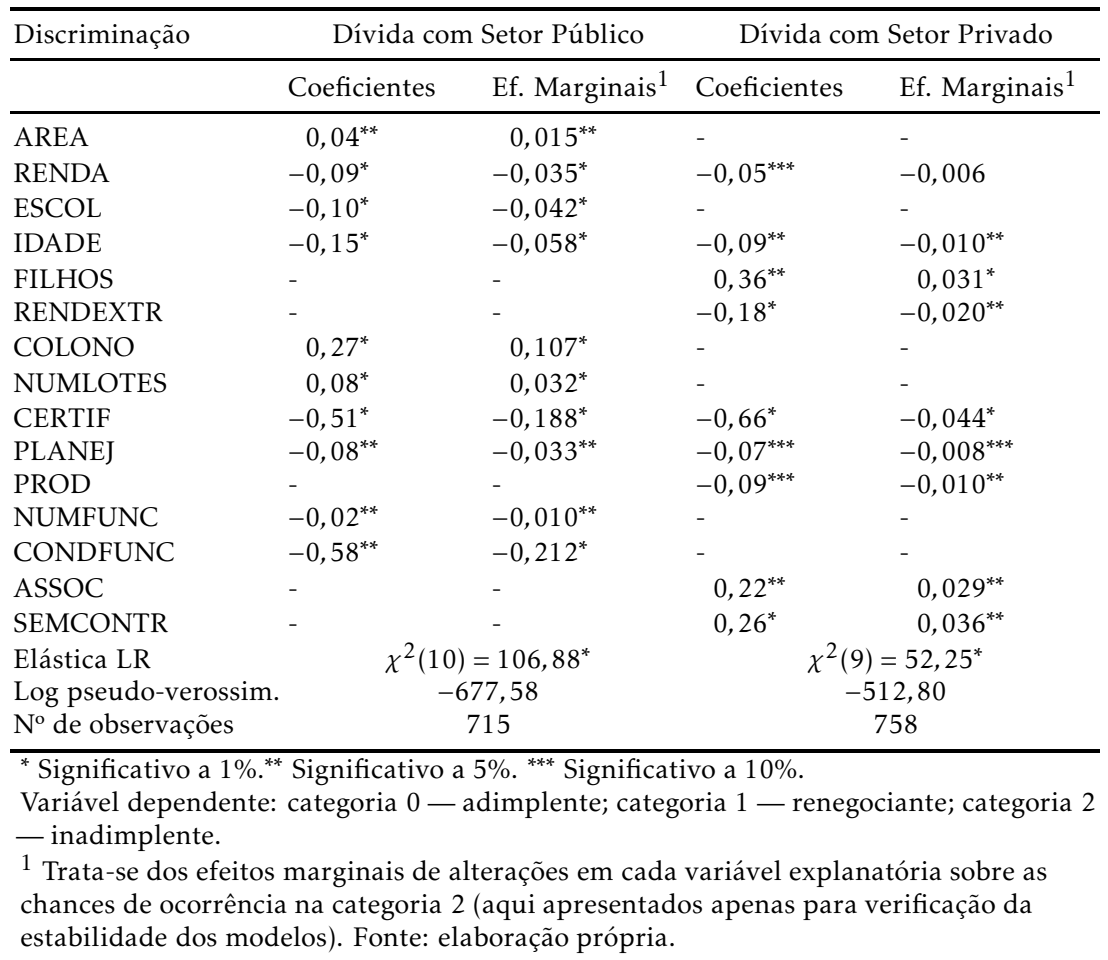

Como observado, a hipótese de divergência dos fatores de influência e seus efeitos marginais quanto ao tipo de crédito é realmente verificada. Para expli-

\footnotetext{
"realiza parcialmente" ou "realiza". Assim, da combinação desses resultados, a variável PROD foi criada variando de zero a quatro, de forma discreta e categórica, elevando-se conforme o grau de realização de manejo produtivo adequado.
} 
car a inadimplência referente às dívidas contraídas junto ao setor público levando-se em conta as instituições bancos públicos e CODEVASF - contam positivamente os fatores AREA, COLONO e NUMLOTES, e negativamente as variáveis RENDA, ESCOL, IDADE, CERTIF, PLANEJ, NUMFUNC e CONDFUNC. Nesse caso, não são significativos ou são redundantes os fatores FILHOS, RENDEXTR, PROD, ASSOC e SEMCONTR. Por sua vez, para explicar a inadimplência às dívidas contraídas junto ao setor privado - levando-se em conta as instituições Distrito de Irrigação e casas comerciais -, contam positivamente os fatores FILHOS, ASSOC e SEMCONTR, e negativamente as variáveis RENDA, IDADE, RENDEXTR, CERTIF, PLANEJ e PROD. Nesse caso, não são significativos ou são redundantes os fatores AREA, ESCOL, COLONO, NUMLOTES, NUMFUNC e CONDFUNC.

Quanto às estimativas dos efeitos marginais, cabe salientar as características medianas do "produtor médio" para todas as variáveis explanatórias dispostas na tabela 5: AREA $=6,3$ (área plantada no lote de 6,3 hectares); RENDA = 1 (renda bruta mensal do lote entre R $\$ 2$ mil e R\$ 3 mil); ESCOL = 4 (com Ensino Médio ou Técnico); IDADE = 3 (entre 50 e 60 anos); FILHOS $=1$ (tem filhos dependentes); RENDEXTR $=1$ (tem renda extra-rural, seja através de aposentadoria ou outra atividade); $\mathrm{COLONO}=0$ (não é caracterizado como colono); NUMLOTES $=1$ (atua em apenas um lote); CERTIF $=0$ (não certificado); PLANEJ = 3 (faz planejamento de negócio de forma parcialforte $\left.^{19}\right)$; PROD = 3 (faz manejo produtivo adequado de forma parcial-forte $\mathrm{e}^{20}$ ); NUMFUNC $=1$ (conta com um único funcionário); CONDFUNC $=0$ (lote não conduzido por funcionário); ASSOC = 0 (não participa de associações); e SEMCONTR $=0$ (apresenta, como principal forma de comercialização, transações por meio de contratos informais ou formais ${ }^{21}$ ). Estas seriam, portanto, as características do "produtor médio" do Polo Petrolina Juazeiro.

Antes de explanar sobre os efeitos marginais, é importante destacar que, de acordo com as estimativas realizadas a partir dos resultados da tabela 5, o "produtor médio" teria diferentes distribuições de probabilidades em cada categoria da variável dependente segundo o tipo de dívida, se contraída com o setor público ou com o setor privado. No caso do modelo para o setor público, a distribuição seria: chances de 16,98\% de ser adimplente nas duas instituições tratadas (bancos comerciais e CODEVASF); 37,43\% de renegociar dívidas com pelo menos uma das duas instituições; e 45,60\% de se tornar inadimplente com pelo menos uma das duas instituições. Por sua vez, para o modelo de setor privado, a distribuição seria: chances de $83,44 \%$ de ser adimplente nas duas instituições tratadas (Distrito de Irrigação e casas comerciais); $10,88 \%$ de renegociar dívidas com pelo menos uma das duas instituições; e $5,68 \%$ de se tornar inadimplente com pelo menos uma das duas instituições.

Esse resultado, portanto, é tratado como a dimensão do fenômeno da inadimplência no Polo Petrolina-Juazeiro, qualificada para o tipo de dívida contraída. Como esperado, os produtores do Polo são mais comprometidos em pagar as dívidas contraídas com o setor privado do que são em pagar as dívidas contraídas junto a instituições públicas. A dimensão dessa divergência indica que as chances de o "produtor médio" ser inadimplente com o setor

\footnotetext{
${ }^{19}$ Como explanado anteriormente.

${ }^{20}$ Como explanado anteriormente.

${ }^{21}$ Contratos informais são tratados como aqueles casos em que o produtor exerce um contrato verbal ou, pelo menos, conhece o comprador devido a transações passadas. Contratos formais são aqueles em que o comprador firma a transação previamente por escrito.
} 
público são 8,03 vezes maiores que as chances de o mesmo ser inadimplente com o setor privado. Por sua vez, as chances de ser renegociante nas dívidas com o setor público são 3,44 vezes maiores que as chances de o produtor ser renegociante com o setor privado. Por fim, as chances de adimplência no setor privado são 4,91 vezes maiores que as chances de adimplência no setor público.

Nesse sentido, o comprometimento ao pagamento das dívidas, por parte dos produtores do Polo, é discrepante segundo o tipo de instituição que se tem relação. A divergência apresentada é significativa, alarmante e reforça a hipótese de que pesa o histórico cultural de que as dívidas públicas serão perdoadas no futuro, o que configura um problema de principal-agente; e que as dívidas contraídas junto ao setor privado são caracterizadas como dívidas de curto prazo, o que leva o produtor a ser mais comprometido em efetuar seus pagamentos, sob o risco de impedir a continuidade de suas explorações produtivas.

Vale salientar que os resultados divergentes quanto à distribuição de probabilidades segundo o tipo de dívida entram em acordo com as observações amostrais a qual aponta para $50,3 \%$ de produtores da amostra como inadimplentes em uma das duas instituições do setor público, enquanto esse percentual é de $9,2 \%$ para o setor privado; $30,2 \%$ de renegociantes com o setor público e $15,5 \%$ com o setor privado; e 19,5\% de adimplentes com o setor público e $75,3 \%$ no caso das dívidas com as duas instituições aqui tratadas para o setor privado.

Passando finalmente aos resultados de efeitos marginais dos fatores determinantes da inadimplência, primeiro serão analisadas aquelas variáveis que são comuns a ambos os modelos, caso dos fatores RENDA, IDADE, CERTIF e PLANEJ. Quanto à variável RENDA, como se esperava, o aumento da renda bruta mensal do lote tende a reduzir as chances de inadimplência, visto que impacta diretamente sobre a capacidade de pagamento dos produtores. Os efeitos marginais referentes a esta variável, apresentados na tabela 6 , indicam que, se o "produtor médio" atingir a faixa 6 (renda acima de R 7 mil), suas chances de inadimplência são reduzidas de $45,60 \%$ para $29,02 \%$ no caso das dívidas com o setor público, enquanto são reduzidas de $5,68 \%$ para $3,35 \%$ no caso do setor privado.

Tabela 6: Efeitos marginais diante de choques na variável RENDA (modelos específicos)

\begin{tabular}{|c|c|c|c|c|c|c|}
\hline \multirow[t]{3}{*}{ Discriminação } & \multicolumn{6}{|c|}{ Distribuição de probabilidades por estrato } \\
\hline & \multicolumn{3}{|c|}{ Setor Público } & \multicolumn{3}{|c|}{ Setor Privado } \\
\hline & Adimpl. & Renegoc. & Inadimpl. & Adimpl. & Renegoc. & Inadimpl. \\
\hline 0: até $\mathrm{R} \$ 2 \mathrm{mil}$ & $14,84 \%$ & $36,05 \%$ & $49,12 \%$ & $82,17 \%$ & $11,56 \%$ & $6,28 \%$ \\
\hline $1^{*}: \mathrm{R} \$ 2-3 \mathrm{mil}$ & $16,98 \%$ & $37,43 \%$ & $45,60 \%$ & $83,44 \%$ & $10,88 \%$ & $5,68 \%$ \\
\hline 2: $\mathrm{R} \$ 3-4$ mil & $19,31 \%$ & $38,58 \%$ & $42,11 \%$ & $84,65 \%$ & $10,21 \%$ & $5,13 \%$ \\
\hline 3: $\mathrm{R} \$ 4-5 \mathrm{mil}$ & $21,82 \%$ & $39,49 \%$ & $38,69 \%$ & $85,81 \%$ & $9,56 \%$ & $4,63 \%$ \\
\hline 4: $\mathrm{R} \$ 5-6 \mathrm{mil}$ & $24,52 \%$ & $40,13 \%$ & $35,35 \%$ & $86,90 \%$ & $8,94 \%$ & $4,16 \%$ \\
\hline 5: R\$ 6-7 mil & $27,38 \%$ & $40,50 \%$ & $32,12 \%$ & $87,93 \%$ & $8,33 \%$ & $3,74 \%$ \\
\hline 6: acima de $\mathrm{R} \$ 7 \mathrm{mil}$ & $30,40 \%$ & $40,58 \%$ & $29,02 \%$ & $88,91 \%$ & $7,74 \%$ & $3,35 \%$ \\
\hline
\end{tabular}

Com respeito à variável IDADE, produtores de maior faixa etária tendem a 
ter maior compromisso de pagamento de suas dívidas. Dessa forma, conforme elucida a tabela 7 , se o "produtor médio" passasse a se caracterizar pela faixa 4 (acima de 60 anos), com tudo mais constante, suas chances de inadimplência seriam reduzidas para $39,82 \%$ no caso das dívidas com o setor público e para $4,75 \%$ no caso do setor privado.

Tabela 7: Efeitos marginais diante de choques na variável IDADE (modelos específicos)

\begin{tabular}{|c|c|c|c|c|c|c|}
\hline \multirow[t]{3}{*}{ Discriminação } & \multicolumn{6}{|c|}{ Distribuição de probabilidades por estrato } \\
\hline & \multicolumn{3}{|c|}{ Setor Público } & \multicolumn{3}{|c|}{ Setor Privado } \\
\hline & Adimpl. & Renegoc. & Inadimpl. & Adimpl. & . Renegoc. & Inadimpl. \\
\hline 0 : até 30 anos & $8,11 \%$ & $28,88 \%$ & $63,00 \%$ & $76,07 \%$ & $14,57 \%$ & $9,36 \%$ \\
\hline 1: $30-40$ anos & $10,56 \%$ & $32,12 \%$ & $57,32 \%$ & $78,71 \%$ & $13,32 \%$ & $7,98 \%$ \\
\hline 2: $40-50$ anos & $13,51 \%$ & $35,02 \%$ & $51,47 \%$ & $81,17 \%$ & $12,08 \%$ & $6,75 \%$ \\
\hline $3^{*}: 40-60$ anos & $16,98 \%$ & $37,43 \%$ & $45,60 \%$ & $83,44 \%$ & $10,88 \%$ & $5,68 \%$ \\
\hline 4: acima de 60 anos & $20,97 \%$ & $39,22 \%$ & $39,82 \%$ & $85,53 \%$ & $9,72 \%$ & $4,75 \%$ \\
\hline
\end{tabular}

Com relaçãoà dummy CERTIF, a existência de certificação faz as chances de o "produtor médio" se tornar inadimplente reduzir consideravelmente, tanto no caso das dívidas contraídas no setor público, quanto no privado. Nesse sentido, no modelo de setor público, a distribuição de probabilidades de um "produtor médio" agora certificado passaria a ser de 32,71\% de ser adimplente, $40,45 \%$ de se tornar renegociante e $26,83 \%$ de ser inadimplente. Por sua vez, no caso do modelo de setor privado, a distribuição passaria a ser de $94,86 \%$ de se tornar adimplente, 3,89\% de ser renegociante e 1,25\% de ser inadimplente.

Quanto à variável PLANEJ, observa-se que a realização de práticas de gestão financeira no negócio tende a reduzir as chances de inadimplência, como apresentado na tabela 8 . Por sua vez, se o "produtor médio" não realiza qualquer gestão financeira, mesmo que parcialmente, suas chances de inadimplência são elevadas para $55,52 \%$ no caso de dívidas contraídas junto ao setor público e para $4,92 \%$ no caso de dívidas no setor privado.

Tabela 8: Efeitos marginais diante de choques na variável PLANEJ (modelos específicos)

\begin{tabular}{|c|c|c|c|c|c|c|}
\hline \multirow[t]{3}{*}{ Discriminação } & \multicolumn{6}{|c|}{ Distribuição de probabilidades por estrato } \\
\hline & \multicolumn{3}{|c|}{ Setor Público } & \multicolumn{3}{|c|}{ Setor Privado } \\
\hline & Adimpl. & Renegoc. & Inadimpl. & Adimpl. & Renegoc. & Inadimpl \\
\hline 0: Não realiza & $11,42 \%$ & $33,06 \%$ & $55,52 \%$ & $77,66 \%$ & $13,82 \%$ & $8,52 \%$ \\
\hline 1: Parcial-fraco & $13,11 \%$ & $34,67 \%$ & $52,22 \%$ & $79,70 \%$ & $12,82 \%$ & $7,47 \%$ \\
\hline 2: Parcial-médio I & $14,96 \%$ & $36,14 \%$ & $48,91 \%$ & $81,63 \%$ & $11,84 \%$ & $6,53 \%$ \\
\hline $3^{*}$ : Parcial-forte & $16,98 \%$ & $37,43 \%$ & $45,60 \%$ & $83,44 \%$ & $10,88 \%$ & $5,68 \%$ \\
\hline 4: Realiza totalmente & $19,16 \%$ & $38,52 \%$ & $42,32 \%$ & $85,13 \%$ & $9,95 \%$ & $4,92 \%$ \\
\hline
\end{tabular}

Passando para a análise dos efeitos marginais dos fatores determinantes da inadimplência unicamente relacionados às dívidas contraídas com o setor público, a variável AREA indica que um aumento de 1 ha sobre a área plantada 
no lote do "produtor médio" (levando-o a se caracterizar por AREA = 7,6) acarretaria uma pequena alteração na distribuição de probabilidades, conforme demonstra a tabela 9. Contudo, o aumento de 10 ha, por exemplo, seria capaz de elevar suas chances de inadimplência de $45,60 \%$ para $61,03 \%$, enquanto reduziria as chances de adimplência para apenas $8,92 \%$. Dessa forma, se o "produtor médio" passar a ter um maior porte, mantendo-se constantes todas as demais características, suas chances de inadimplência às dívidas no setor público tendem a ser elevadas fortemente.

Como comentado anteriormente, vale destacar que a variável AREA mostrouse redundante no modelo explicativo da situação das dívidas dos produtores da amostra relativas ao setor privado.

Tabela 9: Efeitos marginais diante de choques na variável AREA (setor público)

\begin{tabular}{lccc}
\hline Discriminação & \multicolumn{2}{c}{ Distribuição de probabilidades por estrato } \\
\hline & Adimplente & Renegociante & Inadimplente \\
\hline Mínimo amostral (0,2 ha) & $23,67 \%$ & $39,97 \%$ & $36,36 \%$ \\
"Produtor médio" (6,3 ha) & $16,98 \%$ & $37,43 \%$ & $45,60 \%$ \\
1 ha + "produtor médio" (7,3 ha) & $16,01 \%$ & $36,84 \%$ & $47,15 \%$ \\
10 ha + "produtor médio" (16,3 ha) & $8,92 \%$ & $30,05 \%$ & $61,03 \%$ \\
Máximo amostral (28 ha) & $3,57 \%$ & $19,48 \%$ & $76,95 \%$ \\
\hline
\end{tabular}

Fonte: Elaboração própria.

Com respeito à variável ESCOL, verifica-se que uma maior graduação escolar tende a reduzir as chances de inadimplência às dívidas contraídas junto ao setor público, ainda que de forma discreta - se o "produtor médio" passar a ter Ensino Superior, as chances de adimplência crescem para apenas 19,76\%, conforme apresentado na tabela 10. Para o setor privado, por sua vez, a variável ESCOL mostrou-se redundante para explicar a situação da dívida.

Tabela 10: Efeitos marginais diante de choques na variável ESCOL (setor público)

\begin{tabular}{lccc}
\hline Discriminação & \multicolumn{3}{c}{ Distribuição de probabilidades por estrato } \\
\hline & Adimplente & Renegociante & Inadimplente \\
\hline 0: Analfabeto & $8,47 \%$ & $29,42 \%$ & $62,11 \%$ \\
1: Alfabetizado & $10,22 \%$ & $31,72 \%$ & $58,07 \%$ \\
2: Ensino Fundamental I & $12,21 \%$ & $33,85 \%$ & $53,94 \%$ \\
3: Ensino Fundamental II & $14,46 \%$ & $35,77 \%$ & $49,77 \%$ \\
$4^{*}$ : Ensino Médio ou Técnico & $16,98 \%$ & $37,43 \%$ & $45,60 \%$ \\
5: Ensino Superior & $19,76 \%$ & $38,77 \%$ & $41,48 \%$ \\
\hline * Valor referente ao "produtor médio". & & \\
Fonte: Elaboração Própria &
\end{tabular}

Com relação à dummy COLONO, o produtor caracterizado como colono, ou seja, atuando no lote como meeiro, arrendatário ou em regime de comodato, tende a ter maiores chances de ser inadimplente em uma das duas instituições aqui tratadas no âmbito do setor público. Caso o "produtor médio" passasse a ser caracterizado como colono $(\mathrm{COLONO}=1)$, sua distribuição de probabilidades seria alterada para $11,02 \%$ para adimplência, $32,64 \%$ para renegociação e 56,34\% para inadimplência frente às dívidas contraídas junto ao 
setor público. Para o setor privado, contudo, a dummy COLONO mostrou-se redundante para explicar a variável dependente.

O número de lotes em que o produtor atua também influencia a situação da dívida do mesmo frente ao setor público, diferente do que ocorre para o setor privado, como explanado anteriormente, em que a variável NUMLOTES mostrou-se redundante para explicar a inadimplência. Assim, se o "produtor médio" passar a atuar em dois lotes, as chances de inadimplência no setor público são elevadas para $48,80 \%$. No caso de o mesmo assumir o valor máximo amostral, de atuação em dez lotes, referida probabilidade cresce para 73,01\%, conforme apresentado na tabela 11.

Tabela 11: Efeitos marginais diante de choques na variável NUMLOTES (setor público)

\begin{tabular}{lccc}
\hline Discriminação & \multicolumn{2}{c}{ Distribuição de probabilidades por estrato } \\
\hline & Adimplente & Renegociante & Inadimplente \\
\hline "Produtor médio" (1 lote) & $16,98 \%$ & $37,43 \%$ & $45,60 \%$ \\
1 + "produtor médio" (2 lotes) & $15,02 \%$ & $36,18 \%$ & $48,80 \%$ \\
Máximo amostral (10 lotes) & $4,66 \%$ & $22,33 \%$ & $73,01 \%$ \\
\hline Fonte: Elaboração própria. & & &
\end{tabular}

Com respeito à variável NUMFUNC, quanto maior o número de funcionários que trabalha no lote, menores as chances de o produtor se tornar inadimplente frente às dívidas relativas ao setor público, conforme apresenta a tabela 12. Caso o "produtor médio" tenha mais um funcionário, as chances de inadimplência caem para 44,61\%. Apesar da variação discreta, esse é um indicativo de que produtores caracterizados pela agricultura familiar tendem a ter maiores chances de descumprimento às dívidas tomadas no setor público. Como explicado anteriormente, tal sentença não se aplica ao caso das dívidas junto ao setor privado, cuja variável NUMFUNC mostrou-se redundante para explicar a variável dependente.

Tabela 12: .

\begin{tabular}{lccc}
\hline Discriminação & \multicolumn{3}{c}{ Distribuição de probabilidades por estrato } \\
\hline & Adimplente & Renegociante & Inadimplente \\
\hline Mínimo amostral (nenhum funcionário) & $16,35 \%$ & $37,06 \%$ & $46,59 \%$ \\
"Produtor médio" (1 funcionário) & $16,98 \%$ & $37,43 \%$ & $45,60 \%$ \\
1 + "Produtor médio" (2 funcionários) & $17,61 \%$ & $37,77 \%$ & $44,61 \%$ \\
Máximo amostral (56 funcionários) & $66,05 \%$ & $27,00 \%$ & $6,95 \%$ \\
\hline *Valor referente ao "produtor médio". & & & \\
Fonte: Elaboração Própria & & &
\end{tabular}

Por fim, quanto à dummy CONDFUNC, quando o "produtor médio" caracterizase por ter a administração de seu lote conduzido por funcionário, sua distribuição de probabilidades seria de $35,44 \%$ de chances de adimplência, 40,12\% de chances de renegociação e $24,44 \%$ de ser inadimplente quanto às dívidas contraídas junto ao setor público. Nesse sentido, a gestão profissional do negócio, no caso da amostra aqui analisada, tende a elevar as chances de adimplência do produtor. Contudo, para as dívidas no setor privado, a dummy CONDFUNC mostra-se redundante para explicar a inadimplência. 
Passando para a análise dos efeitos marginais dos fatores determinantes da inadimplência unicamente relacionados às dívidas contraídas com o setor privado, a dummy FILHOS, referente à existência de filhos dependentes, indica uma relação positiva com a inadimplência nesse tipo de dívida. Assim, se o "produtor médio' não possuísse filhos dependentes, sua distribuição de probabilidades seria de $90,85 \%$ de chances de adimplência, $6,54 \%$ de chances de renegociação e $2,61 \%$ de ser inadimplente. Portanto, a inexistência de filhos dependentes tende a reduzir a probabilidade de o produtor não cumprir suas obrigações frente às dívidas contraídas junto ao setor privado. Quanto ao setor público, contudo, referida dummy é redundante para explicar a variável dependente.

Por sua vez, quanto à dummy RENDEXTR, o "produtor médio" caracterizase por possuir algum tipo de renda extrarrural, seja através de aposentadoria ou através de outra atividade. Caso este não possuísse renda extrarrural, sua distribuição de probabilidades seria de $78,66 \%$ de chances de adimplência, $13,34 \%$ de chances de renegociação e $8,00 \%$ de ser inadimplente quanto às dívidas contraídas junto ao setor privado. Quanto ao setor público, assim como descrito para a dummy FILHOS, a disponibilidade de renda extra-rural é redundante para explicar a inadimplência.

Com respeito à variável PROD, esta tende a reduzir as chances de inadimplência no setor privado, diferente do que ocorre no caso das dívidas contraídas no setor público, cuja variável é redundante para explicar a categoria em que o produtor se encontra. Assim, observa-se que a realização de práticas produtivas adequadas tende a reduzir as chances de inadimplência no setor privado, como apresentado na tabela 13. Por sua vez, se o "produtor médio" não realiza qualquer manejo produtivo, mesmo que parcialmente, suas chances de inadimplência são elevadas para 9,29\%.

Tabela 13: Efeitos marginais diante de choques na variável PROD (setor privado)

\begin{tabular}{lccc}
\hline Discriminação & \multicolumn{2}{c}{ Distribuição de probabilidades por estrato } \\
\hline & Adimplente & Renegociante & Inadimplente \\
\hline 0: Não realiza manejo adequado & $76,20 \%$ & $14,51 \%$ & $9,29 \%$ \\
1: Realiza / parcialmente-fraco & $78,79 \%$ & $13,28 \%$ & $7,94 \%$ \\
2: Realiza / parcialmente-médio I & $81,20 \%$ & $12,06 \%$ & $6,74 \%$ \\
3*: Realiza / parcialmente-forte & $83,44 \%$ & $10,88 \%$ & $5,68 \%$ \\
4: Realiza completamente & $85,50 \%$ & $9,74 \%$ & $4,76 \%$ \\
\hline *Valor referente ao "produtor médio". & & \\
Fonte: Elaboração Própria &
\end{tabular}

Quanto à dummy ASSOC, quando o "produtor médio" caracteriza-se por participar de associação de produtores, sua distribuição de probabilidades seria de $77,50 \%$ de chances de adimplência, $13,90 \%$ de chances de renegociação e $8,60 \%$ de ser inadimplente quanto às dívidas contraídas junto ao setor privado. Nesse sentido, a participação em associações tende a elevar as chances de inadimplência do produtor ${ }^{22}$. Contudo, para as dívidas no setor público, a dummy ASSOC mostra-se redundante para explicar a inadimplência.

\footnotetext{
${ }^{22}$ Tal resultado pode estar associado a fatores como pouca atuação e desvalorização das organizações de produtores no Polo.
} 
Por fim, com respeito à dummy SEMCONTR, o "produtor médio" apresenta, como principal forma de comercialização, transações por meio de contratos informais ou formais. Assim, se o "produtor médio" efetuasse suas vendas por meio de estruturas menos coordenadas de transação, sua distribuição de probabilidades seria de 76,19\% de chances de adimplência, 14,51\% de chances de renegociação e $9,29 \%$ de ser inadimplente quanto às dívidas contraídas junto ao setor privado. Para as dívidas no setor público, referida variável mostra-se redundante para explicar a variável dependente.

Ademais, cabe ressaltar que a análise dos efeitos marginais foi feita individualmente para cada variável explanatória, segundo cada modelo estimado (conjunto e específicos). Em todas as análises, os choques provocados foram individuais, mantendo-se constantes as demais variáveis. Contudo, é óbvio que a distribuição de probabilidades poderá ser alterada diante de choques conjuntos. Dessa forma, foram aqui apresentados modelos que permitem a estimativa das chances de produtores com características variadas serem ou não adimplentes, renegociantes ou inadimplentes, configurando-se, portanto, em importante ferramenta para se levantar hipóteses sobre o risco de crédito relativo a cada produtor.

Por exemplo, considere-se um produtor cujas características são favoráveis e descritas como: $A R E A=6,3$ (equivalente à área plantada no lote do "produtor médio"); RENDA = 6 (renda mensal do lote acima de R\$ 7 mil); ES$\mathrm{COL}=5$ (com Ensino Superior); IDADE $=3$ (entre 50 e 60 anos, equivalente ao "produtor médio"); FILHOS = 1 (tem filhos dependentes, como o "produtor médio"); RENDEXTR = 1 (tem renda extra-rural, equivalente ao "produtor médio"); COLONO = 0 (não é caracterizado como colono, assim como o "produtor médio"); NUMLOTES = 1 (atua em apenas um lote, assim como o "produtor médio"); CERTIF = 1 (tem certificação); PLANEJ = 4 (faz gerenciamento financeiro); PROD = 4 (faz manejo produtivo adequado); NUMFUNC $=6$ (conta com seis funcionários - um por hectare plantado); CONDFUNC $=0$ (lote não conduzido por funcionário, equivalente ao "produtor médio"); ASSOC $=0$ (não participa de associações, equivalente à área do "produtor médio"); e SEMCONTR = 0 (transaciona por meio de contratos informais e/ou formais, assim como o "produtor médio").

Como contraponto, considere-se outro exemplo, de um produtor cujas características são desfavoráveis e descritas como: $\mathrm{AREA}=6,3$ (equivalente à área plantada no lote do "produtor médio"); RENDA $=0$ (renda bruta mensal do lote inferior a R\$2 mil); ESCOL = 5 (com Ensino Médio ou Técnico, assim como o "produtor médio"); IDADE = 3 (entre 50 e 60 anos, assim como o "produtor médio"); FILHOS = 1 (tem filhos dependentes, assim como o "produtor médio"); RENDEXTR = 0 (não tem renda extra-rural); COLONO = 0 (não é caracterizado como colono, equivalente ao "produtor médio"); NUMLOTES = 1 (atua em apenas um lote, equivalente ao "produtor médio"); CERTIF = 0 (não tem certificação, equivalente ao "produtor médio"); PLANEJ = 0 (não faz qualquer gerenciamento financeiro, mesmo que parcialmente); $\mathrm{PROD}=0$ (não faz manejo produtivo adequado, mesmo que parcialmente); NUMFUNC $=1$ (conta com um funcionário, assim como o "produtor médio"); CONDFUNC = 0 (lote não conduzido por funcionário, assim como o "produtor médio"); ASSOC $=0$ (não participa de associações, assim como o "produtor médio"); e SEMCONTR $=1$ (não transaciona por meio de contratos, mesmo informais).

No caso do produtor com condições favoráveis, as chances de adimplência estimadas seriam de 54,73\% no modelo conjunto, 62,04\% no modelo espe- 
cífico referente ao setor público e $97,92 \%$ no modelo específico referente ao setor privado. Por outro lado, no caso do produtor com condições desfavoráveis, as chances de adimplência estimadas seriam de apenas $7,15 \%$ no modelo conjunto, 9,80\% no modelo específico referente ao setor público e 50,62\% no modelo específico referente ao setor privado.

\subsection{Ajustes dos Modelos}

Para efeitos de exercício para uma medida de ajuste dos modelos aos dados amostrais, foram calculadas as probabilidades de ocorrência em cada uma das categorias da variável dependente em cada modelo estimado - dadas as informações observadas para o vetor $X-$, sendo esses resultados confrontados com o valor realmente observado da variável dependente. Para tanto, foram considerados como erros as seguintes ocorrências: i) indicar ser mais provável ser adimplente quando, na verdade, o produtor foi inadimplente ou renegociante; ii) indicar ser mais provável ser inadimplente quando, na verdade, o produtor foi adimplente ou renegociante; e iii) indicar ser mais provável ser renegociante quando, na verdade, o produtor foi adimplente ou inadimplente. Dessa maneira, verificou-se que houve $56,45 \%$ de acertos no caso do modelo conjunto (dentre as 659 observações utilizadas nesse modelo), 56,22\% no modelo específico para o setor público (dentre as 715 observações utilizadas) e $76,12 \%$ no modelo específico para o setor privado (dentre as 758 utilizadas).

Obviamente, ao se relaxar as condições de erro propostas, os resultados são ainda mais satisfatórios. Assim, resolveu-se dar uma medida de ajuste apenas sobre os casos extremos, de adimplência e inadimplência. Nesse caso, verificou-se que:

- Quanto ao modelo conjunto: i) se as estimativas indicaram maior probabilidade de que o produtor fosse adimplente nas quatro instituições consideradas, em $83,3 \%$ desses casos este não foi inadimplente em nenhuma delas; e ii) se as estimativas indicaram maior probabilidade de que o produtor fosse inadimplente em uma das quatro instituições consideradas, em 90,5\% desses casos este não foi adimplente em todas elas;

- Quanto ao modelo específico para o setor público: i) se as estimativas indicaram maior probabilidade de que o produtor fosse adimplente nas duas instituições consideradas, em $82,7 \%$ desses casos este não foi inadimplente em nenhuma delas; ii) se as estimativas indicaram maior probabilidade de que o produtor fosse inadimplente em uma das duas instituições consideradas, em $87,1 \%$ desses casos este não foi adimplente em todas elas;

- Quanto ao modelo específico para o setor privado: em todas as observações, as estimativas indicaram maior probabilidade de que o produtor fosse adimplente nas duas instituições consideradas e, assim, em 90,1\% desses casos este não foi inadimplente em nenhuma delas.

Tais resultados indicam um ajuste satisfatório para o levantamento de hipóteses sobre o risco de crédito relativo a cada produtor. 


\section{Considerações Finais}

Diante dos resultados apresentados, verifica-se que a dimensão da inadimplência no Polo Petrolina-Juazeiro é preocupante, no sentido de que as chances de um "produtor médio" do Polo se tornar inadimplente em pelo menos uma das quatro instituições aqui tratadas (bancos públicos, CODEVASF, Distrito de Irrigação e casas comerciais) chega a 46,09\%. Do lado oposto, a probabilidade de adimplência em todas as quatro instituições chega a somente 14,64\%, enquanto as chances de renegociação chegam a $39,26 \%$.

Contudo, verificou-se que o descompromisso com as dívidas por parte dos produtores do Polo varia de acordo com o tipo de instituição. Nesse sentido, verifica-se que o problema da inadimplência no Polo está fortemente relacionado com as dívidas contraídas junto a instituições do setor público, aqui tratadas como os bancos públicos e a CODEVASF. Para o caso das dívidas com o setor público, a estimativa das chances de inadimplência chega a 45,60\%, cerca de 8 vezes mais do que as chances de inadimplência no setor privado aqui representado pelo Distrito de Irrigação e pelas casas comerciais. Do lado oposto, a probabilidade de adimplência no setor privado chega a $83,44 \%$, enquanto que no setor público essas chances são de apenas 16,98\%. Na situação intermediária, de renegociação das dívidas, as chances no setor público foram estimadas em 37,43\%, valor 3,4 vezes maior que as chances de renegociação com uma das duas instituições aqui tratadas como sendo do setor privado.

Além disso, os fatores determinantes da situação das dívidas são peculiares a cada tipo de endividamento. No caso da adimplência às dívidas com o setor público, pesam positivamente a renda bruta do lote, a escolaridade e a idade do produtor, a existência de certificação (Globalgap), a realização de práticas de gerenciamento financeiro, o número de funcionários no lote e produtores com funcionários que conduzem o lote; e negativamente a área plantada no lote, a condição de colono (meeiro, arrendatário ou em regime de comodato) e o número de lotes em que o produtor atua. Por outro lado, para a adimplência às dívidas com o setor privado, pesam positivamente a renda bruta do lote, a idade do produtor, a existência de renda extra-rural, a existência de certificação (Globalgap), a realização de práticas de gerenciamento financeiro e manejo produtivo adequado; e negativamente a condição de ter filhos dependentes, participar de associações e não vender suas frutas por meio de contratos informais e/ou formais.

Os resultados encontrados neste trabalho concatenam com os encontrados por autores como Antão \& Campanholo (2011), Villa Verde (2000) e Costa (2007), onde se mostra que existe uma tendência no sentido dos produtores agrícolas serem menos comprometidos em pagar as dívidas junto ao setor público do que em relação ao setor privado. Isso se deve sobretudo ao histórico cultural de que as dívidas públicas seriam perdoadas no futuro e também por essas dívidas se caracterizarem como dívidas de longo prazo (menos comprometimento em efetuar seus pagamentos). As dívidas contraídas junto ao setor privado, ao contrário, seriam dívidas de curto prazo, o que afetaria diretamente as atividades de exploração produtiva e, consequentemente, sua continuidade.

Vale destacar que a análise do modelo conjunto aponta para a situação geral da inadimplência no Polo, sem qualificar o tipo de instituição em que as dívidas são contraídas. Por esse motivo, seus resultados concatenam os fenômenos específicos da inadimplência frente ao setor público e frente ao setor 
privado. Ademais, os diagnósticos de ajuste dos modelos estimados (conjunto e específicos) apontam para níveis satisfatórios que permitem a utilização dos mesmos para inferir sobre o risco de crédito associado a determinado produtor que se deseja estudar, diante de suas características.

Ante ao acima exposto, o foco de políticas setoriais deve recair sobre os seguintes aspectos: i) incentivar a realização de práticas de gerenciamento financeiro entre os produtores; ii) promover o acesso dos produtores a técnicas produtivas que elevem a produtividade dos cultivos explorados; iii) estimular a adequação dos produtores aos níveis de tecnologia e qualidade exigidos internacionalmente; iv) efetuar medidas de redução da incidência do comércio realizado por meio de atravessadores, estimulando a realização de contratos entre produtores e demandantes (garantia de preço); v) reformular a gestão das organizações de produtores locais, dando maior dinamismo às estratégias de associativismo; vi) dar especial atenção aos colonos, estimulando práticas produtivas e gerenciais adequadas; e vii) promover medidas voltadas à melhoria da qualidade de ensino na região, principalmente do ensino técnico aplicado à agricultura, com potenciais efeitos de longo prazo. Para que a problemática atual da inadimplência seja contornada, é necessário que medidas nesse sentido sejam colocadas em prática, com o objetivo de se buscar, de maneira responsável e construtiva, uma solução racional e justa, com a participação e envolvimento dos produtores e seus agentes relacionados, dos bancos, da sociedade e do Governo.

\section{Referências Bibliográficas}

Akerlof, G. (1970), 'The market for lemons: Qualitative uncertainty and the market mechanism', Quarterly Journal of Economics 3(84), 488-500.

Antão, R. A. S. \& Campanholo, T. (2011), 'O crédito rural no contexto do desenvolvimento econômico e social', Revista da Católica 3(5), 1-12.

Arrow, K. J. (1971), Essays in the Theory of Risk-Bearing, Markham Publishing Co.

Azevedo, C. M. \& Shikida, P. F. A. (2004), 'Assimetria de informação e o crédito agropecuário: o caso dos cooperados da coamo-toledo (pr)', Revista de Economia e Sociologia Rural 42(2), 267-292.

Brant, R. (1990), 'Assessing proportionality in the proportional odds model for ordinal logistic regression', Biometrics 46(4), 1171-8.

Caouette, J. B., Altman, E. I. \& Narayanan, P. (1999), Gestão do Risco de Crédito, Qualitymark Editora Ltda.

Cardoso, L. V. (2005), Coordenação e competitividade no sistema agroindustrial de mamão: estudo multicaso de firmas exportadoras, Dissertação (mestrado em agronegócios), UFMS/UFGO/UNB, Brasília-DF.

Chaddad, F. R. \& Lazzarini, S. G. (2003), 'Relações contratuais de crédito agrícola e o papel dos agentes financeiros privados: teoria e evidências dos eua', Revista de Economia e Sociologia Rural 41(3), 29-52. 
CODEVASF (2012), 'Companhia de desenvolvimento dos vales do são francisco e do parnaíba'. http://www.codevasf.gov.br/. Acessado em junho de 2012.

Costa, J. G. (2007), Entraves e alternativas para a expansão do crédito rural na fruticultura irrigada do polo petrolina-juazeiro, Dissertação (mestrado em economia), UFPE, Recife-PE.

Costa, S. M. A., Gomes, M. R. L. \& Tarsitano, M. A. A. (2008), 'A comercialização de uvas finas na região de jales-sp', Revista Brasileira de Fruticultura 30(1), 127-132.

Davidson, R. \& MacKinnon, J. (2003), Econometric theory and methods, 1 ed. edn, Oxford University Press.

Dias, G. L. S. (1991), 'Mobilização de poupança e o financiamento do setor agrícola', Piracicaba: FEALQ/CEPEA.

Faria, R. N., Souza, R. C., Vieira, J. G. V. \& Lírio, V. S. (2008), 'Custo de transação e exigências técnicas nas exportações de manga e de mamão', Informações Econômicas 38(5), 59-71.

Franca, C. S. (2004), Impacto da globalização e modernização agrícola na região do vale submédio do são francisco: estudo de caso do perímetro de irrigação projeto bebedouro em petrolina - pe, Dissertação (mestrado em sociologia), UFPE, Recife-PE.

Gatti, E. U., Vieira, J. L. T. M. \& Silva, V. (1993), 'Análise do perfil distributivo do crédito rural no brasil, 1969-90', Agricultura em São Paulo 40(1), 65-99.

Greene, W. H. (2003), Econometric Analysis, 5 ed. edn, Prentice Hall.

Guanziroli, C. E. (2007), 'Pronaf dez anos depois: resultados e perspectivas para o desenvolvimento rural', Revista de Economia e Sociologia Rural 45(2), 301-328.

Lazzarini, S. G., Neves, M. F. \& Chaddad, F. R. (1999), 'Pacotes de insumos agrícolas: Mudando a configuração do agribusiness', Preços Agrícolas 13(154), 52-53.

Ortega, A. C. \& Só, L. S. (2005), 'Impacto das políticas do mda: um estudo de caso do pronaf nos municípios de orizona e davinópolis em goiás (brasil)', Anais..., Santiago, Chile.

PRONAF (2006), 'Programa nacional de fortalecimento da agricultura familiar’. http://portal.mda.gov.br/portal/saf/programas/pronaf. Acessado em junho de 2014.

Rocha Júnior, W. F. (2001), A matriz estrutural prospectiva com o enfoque da nova economia institucional: o caso do agronegócio da erva-mate, Tese (doutorado em economia), UFSC, Florianópolis-SC.

Sherrick, B. J., Sonka, S. \& Monke, J. D. (1994), 'Nontraditional lenders in agricultural credit markets', Agribusiness 10(4), 341-357. 
Sobel, T. F. (2011), Fruticultura e Economia dos Custos de Transação: determinantes das estruturas de governança dos pequenos produtores do Polo Petrolina-Juazeiro, Tese (doutorado em economia), UFPE, Recife-PE.

STATA (2012), 'Data analysis and statistical software'. http://www.stata.com/. Acessado em junho de 2012.

Staten, M. E., Gilley, O. W. \& Umbeck, J. (1990), 'Information costs and the organization of credit markets: A theory of indirect lending', Economic Inquiry 28(3), 508-29.

Stiglitz, J. E. (2000), 'The contributions of the economics of information to twentieth century economics', Quarterly Journal of Economics 115(4), 14411478 .

Stiglitz, J. E. \& Weiss, A. (1981), 'Credit rationing in markets with imperfect information', American Economic Review 71(3), 393-410.

Trombin, V. G. (2007), Proposição de um método para analisar a viabilidade da implantação de uma cadeia produtiva em um novo local: o caso da citricultura no pólo petrolina juazeiro, Dissertação (mestrado em administração de organizações), USP, São Paulo-SP.

Villa Verde, C. M. (2000), 'O crédito rural e a capacidade de pagamento do setor agrícola', IPEA, Brasília.

Wang, X. \& Kockelman, K. M. (2005), 'Occupant injury severity using a heteroscedastic ordered logit model: distinguishing the effects of vehicle weight and type', Annals of..., Washington.

Williamson, O. E. (1995), The economic institutions of capitalism, The Free Press.

Wolfe, F. \& Gould, W. (1998), 'An approximate likelihood-ratio test for ordinal response models', Stata Technical Bulletin 7(42), 24-27.

Zylbersztajn, D. (2005), 'Papel dos contratos na coordenação agro-industrial: um olhar além dos mercados', Revista de Economia e Sociologia Rural 43(3), 385-420. 